\title{
Asymmetries of Dark and Bright Negative Afterimages Are Paralleled by Subcortical ON and OFF Poststimulus Responses
}

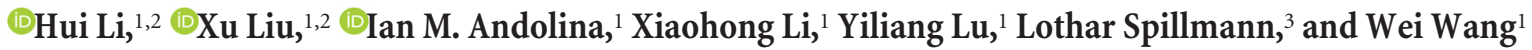 \\ ${ }^{1}$ Institute of Neuroscience, State Key Laboratory of Neuroscience, Key Laboratory of Primate Neurobiology, Center for Excellence in Brain Science and \\ Intelligence Technology, Chinese Academy of Sciences, Shanghai 200031, China, ${ }^{2}$ University of Chinese Academy of Sciences, Shanghai 200031, China, and \\ ${ }^{3}$ Department of Neurology, University of Freiburg, 79085 Freiburg, Germany
}

Humans are more sensitive to luminance decrements than increments, as evidenced by lower thresholds and shorter latencies for dark stimuli. This asymmetry is consistent with results of neurophysiological recordings in dorsal lateral geniculate nucleus (dLGN) and primary visual cortex (V1) of cat and monkey. Specifically, V1 population responses demonstrate that darks elicit higher levels of activation than brights, and the latency of OFF responses in $\mathrm{DLGN}$ and $\mathrm{V} 1$ is shorter than that of ON responses. The removal of a dark or bright disc often generates the perception of a negative afterimage, and here we ask whether there also exist asymmetries for negative afterimages elicited by dark and bright discs. If so, do the poststimulus responses of subcortical ON and OFF cells parallel such afterimage asymmetries? To test these hypotheses, we performed psychophysical experiments in humans and single-cell/S-potential recordings in cat dLGN. Psychophysically, we found that bright afterimages elicited by luminance decrements are stronger and last longer than dark afterimages elicited by luminance increments of equal sizes. Neurophysiologically, we found that $\mathrm{ON}$ cells responded to the removal of a dark disc with higher firing rates that were maintained for longer than OFF cells to the removal of a bright disc. The ON and OFF cell asymmetry was most pronounced at long stimulus durations in the dLGN. We conclude that subcortical response strength differences between ON and OFF channels parallel the asymmetries between bright and dark negative afterimages, further supporting a subcortical origin of bright and dark afterimage perception.

Key words: afterimage; asymmetry; LGN; OFF; ON

\section{Significance Statement}

Afterimages are physiological aftereffects following stimulation of the eye, the study of which helps us to understand how our visual brain generates visual perception in the absence of physical stimuli. We report, for the first time to our knowledge, asymmetries between bright and dark negative afterimages elicited by luminance decrements and increments, respectively. Bright afterimages are stronger and last longer than dark afterimages. Subcortical neuronal recordings of poststimulus responses of ON and OFF cells reveal similar asymmetries with respect to response strength and duration. Our results suggest that subcortical differences between $\mathrm{ON}$ and OFF channels help explain intensity and duration asymmetries between bright and dark afterimages, supporting the notion of a subcortical origin of bright and dark afterimages.

\section{Introduction}

Human psychophysical experiments have suggested that detection thresholds are lower (Blackwell, 1946; Herrick, 1956; Short,
1966; Whittle, 1986; Kontsevich and Tyler, 1999; Chubb and Nam, 2000; however see Komban et al., 2011), and detection latencies are shorter (Komban et al., 2011, 2014) for luminance decrements (dark) compared with contrast-matched luminance

Correspondence should be addressed to either Dr. Ian M. Andolina or Dr. Wei Wang, Institute of Neuroscience, 320 Yueyang Road, Neurosciences Building, Room 203, Shanghai 200031, China. E-mail: i.andolina@ion.ac.cn or w.wang@ion.ac.cn.

L. Spillmann is on a leave of absence from the Department of Neurology, University of Freiburg, 79085 Freiburg, Germany.

DOI:10.1523/JNEUROSCI.2021-16.2017

Copyright $\odot 2017$ the authors $\quad 0270-6474 / 17 / 371984-13 \$ 15.00 / 0$ 
A
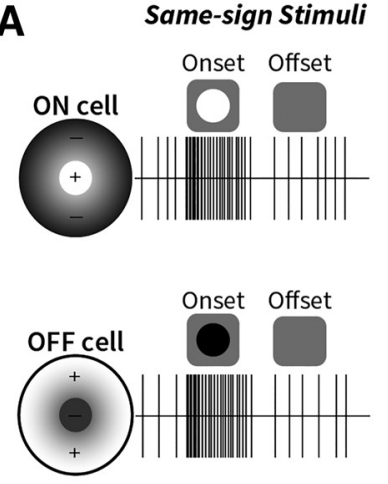

Stimulus and post-stimulus responses of ON and OFF cells to bright and dark flashed discs
Opposite-sign Stimuli
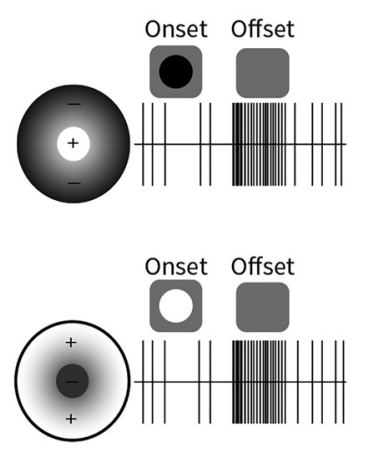

(n)

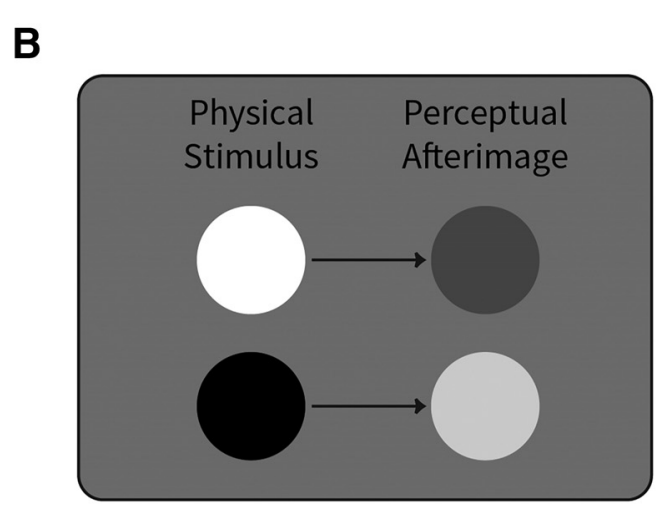

Bright and dark flashed discs elicit negative afterimages

Figure 1. Possible explanation for negative afterimage formation. $\boldsymbol{A}$, Schematic $0 \mathrm{~N}$ cell responses to the onset of a bright stimulus and offset of a dark stimulus, and vice versa for OFF cells. $\boldsymbol{B}$, Removal of bright stimulus after adaptation causes a dark afterimage, whereas removal of a dark stimulus after adaptation causes a bright afterimage. One plausible hypothesis for negative afterimages suggests an origin in subcortical responses to the opposite-sign stimulus offset.

increments (bright). Dark stimuli elicit stronger EEG responses than bright stimuli (Zemon et al., 1988), and these asymmetries are consistent with the observation that we read faster and make fewer errors when reading black-on-white script compared with white-on-black script (Buchner and Baumgartner, 2007). It is known that subcortical OFF and ON cells in the retina and dLGN with antagonistic center-surround receptive fields (RFs, Fig. 1A) signal such luminance decrements and increments, respectively (Hartline, 1938; Barlow, 1953; Kuffler, 1953; Baumgartner, 1961; Jung, 1973; Schiller, 1995). The perceptual asymmetries would predict that there should be cellular differences between OFF (dark) and ON (bright) channels. In the retina, the OFF bipolar and retinal ganglion cells (RGCs) are numerically greater, and the dendritic arbors are narrower for OFF RGCs (Ahmad et al., 2003; Ratliff et al., 2010). In addition, there are clear asymmetries in the cross talk between the two channels; ON bipolar cells drive cross-inhibition to suppress OFF responses but not vice versa (Zaghloul et al., 2003; Manookin et al., 2008; Liang and Freed, 2010). This improves the information encoding efficiency of RGCs for dark stimuli (Liang and Freed, 2012).

Further along the visual pathway, results from neural recordings in dLGN and V1 of cat and monkey show that these retinal channel asymmetries are maintained and enhanced. V1 population responses elicited by dark stimuli are stronger than those elicited by bright stimuli, and OFF-dominant cells also outnumber ON-dominant cells (Jin et al., 2008; Yeh et al., 2009; Xing et al., 2010; Zurawel et al., 2014). In addition, neurons in cat dLGN and $\mathrm{V} 1$ are shown to respond faster to luminance decrements than to luminance increments (Jin et al., 2011; Komban et al., 2014; Rekauzke et al., 2016). Both the substantial cellular asymmetries from the retina onwards and resultant psychophysical asymmetries for dark versus bright stimuli are consistent with the fact that dark (negative) contrasts are far more prevalent in natural scenes than bright (positive) contrasts (Ratliff et al., 2010).

An afterimage is a type of physiological aftereffect in which an image continues to be seen briefly after the actual stimulus has been removed (Wheatstone, 1838). A negative afterimage is seen following exposure to a dark or bright disc (Fig. 1B). ON and OFF cells in the retina and dLGN respond strongly to the offset of such stimuli (Singer and Creutzfeldt, 1970; Krüger and Fischer, 1975; Schiller, 1982, 1995). It has long been proposed that the poststimulus offset response of OFF cells gives rise to the dark afterimage and conversely that the poststimulus response of ON cells gives rise to the bright afterimage (Jung, 1973; Schiller and Dolan, 1994; Schiller, 1995). RGC offset responses have also recently been linked to color afterimage perception (Zaidi et al., 2012). Because of the recent appreciation of the response asymmetry between dark and bright stimuli, here we ask whether they also elicit asymmetrical negative afterimages. If so, can these asymmetries be attributed to neuronal differences between subcortical $\mathrm{ON}$ and OFF channels? To answer these questions, we conducted psychophysical experiments in human observers and single-unit/ S-potential recordings in cat dLGN. Psychophysically, we found that bright afterimages elicited by dark-disc stimuli are stronger and perceived for longer, compared with those elicited by brightdisc stimuli at equal contrasts. Subsequent neuronal recordings in dLGN revealed that the perceptual asymmetries with respect to strength and duration for bright and dark afterimages were paralleled with the asymmetries between poststimulus responses of $\mathrm{ON}$ and OFF cells (and putative RGCs via S-potentials). These findings support a subcortical origin for bright and dark negative afterimages.

\section{Materials and Methods}

Human psychophysics. Eight male subjects, three of whom were authors (age 24-42 years) participated in the experiments. The subjects gave written consent to the procedure in accordance with institutional guidelines and the Declaration of Helsinki. All had normal or corrected-tonormal vision, had no history of psychiatric or neurological disorders, and were paid for their participation. Experiments were approved by the Ethics Committee of the Institute of Neuroscience, Chinese Academy of Sciences. Subjects practiced for at least 6 sessions before data acquisition. Subjects sat in a dark room at a distance of $0.57 \mathrm{~m}$ from a CRT monitor subtending a visual angle of $37.8^{\circ} \times 28^{\circ}$ (Sony Trinitron Multiscan G520, 21 inches, $1280 \times 1024$ pixels, $85 \mathrm{~Hz}$ ). Stimulus generation, presentation, and data acquisition were controlled by a personal computer running the Psychophysics toolbox version 3.0.13 (RRID:SCR_002881, Kleiner et al., 2007) within MATLAB (RRID:SCR_001622, The MathWorks). The luminance output of the CRT monitor was linearized using a corrected color lookup table generated by a ColorCAL colorimeter (Cambridge Research Systems). The luminance range of the screen was $0.1-120 \mathrm{~cd} / \mathrm{m}^{2}$. A chin-forehead rest was used to stabilize the head. A small black cross subtending $0.4^{\circ}$ was presented at the center of the screen. Subjects were asked to fixate at the central cross with their left eye while their right eye was occluded for the duration of the experiment. We used an SR Research Eyelink 1000 eyetracker (RRID:SCR_009602) to monitor for any eye movement and blink-related variability in afterimage perception, aborting any trial where fixational eye movements exceeded a circular 
radius around the fixation cross of $0.75^{\circ}$. All stimulus disc edges were smoothed with cubic Hermite interpolation with a $\sigma$ of $0.35^{\circ}$ (afterimage contrast) or $0.18^{\circ}$ (afterimage duration and masking latency) to further minimize microsaccadic edge effects (Bachy and Zaidi, 2014). To ensure that any remaining fixational eye movements were not responsible for the perceived differences between dark and bright afterimages, we analyzed the fixational microsaccades for the duration of the subject's fixation period using a velocity and duration algorithm (Engbert and Mergenthaler, 2006; Jones et al., 2015); there was no difference in the number of microsaccades per second between bright and dark conditions (dark: $2.2 \pm 0.08 \mathrm{SE} \mid$ bright: $2.1 \pm 0.07 \mathrm{SE} ; p=0.18$ Wilcoxon rank sum). We presented all psychophysical stimuli at 1 of 6 parafoveal positions radially positioned $3^{\circ}$ away from the center of fixation. We defined the floating-point luminance range of the screen between 0 and 1: 0 denoting the darkest luminance $\left(0.1 \mathrm{~cd} / \mathrm{m}^{2}\right)$, and 1 denoting the brightest luminance $\left(120 \mathrm{~cd} / \mathrm{m}^{2}\right)$. Luminance of the background was set to 0.5 $\left(60 \mathrm{~cd} / \mathrm{m}^{2}\right)$. Linear steps of contrast were used across the psychophysical and neurophysiological studies (Kremkow et al., 2014), and were defined by the difference between the stimulus and the 0.5 background. For example, contrast of the brightest (positive) stimulus here is $1-0.5=$ 0.5 , contrast of the background is $0.5-0.5=0$, while contrast of the darkest (negative) stimulus here is $0-0.5=-0.5$.

Measurement of afterimage contrast. To measure the perceived afterimage contrast, dark (luminance value: 0 ) and bright (luminance value: 1 ) $3^{\circ}$ diameter discs were presented for $4 \mathrm{~s}$ at 1 of 6 random equidistant positions around the fixation point in a random method of constants sequence. Immediately after the stimulus disc was turned off, a variable contrast $(0, \pm 0.05, \pm 0.1, \pm 0.15, \pm 0.2, \pm 0.25, \pm 0.3, \pm 0.35, \pm 0.4)$ pedestal of the same size, position, and contrast sign was presented. To restrict the measurement to the transient (Purkinje) phase of the afterimage (Jung, 1973), the pedestal was presented for only $400 \mathrm{~ms}$ when a grating mask was presented at the same location for one second (sinusoid grating parameters: $45^{\circ}$ orientation, 3 cycles $/{ }^{\circ}$ spatial frequency, 2 cycles/s temporal frequency). Each pedestal contrast was repeated for 9 trials, and results were averaged. The subjects were asked to respond whether they observed anything visible between the stimulus turning off and mask turning on. If nothing was seen other than the mean background luminance (0.5), this was considered a perceptual null. If they did perceive something, they had to report if the perception was brighter or darker than the background. If the perception was brighter than the background, the subject saw the pedestal for bright stimuli and an afterimage for dark stimuli; if the perception was darker than the background, the subject saw an afterimage for bright stimuli and the pedestal for dark stimuli. We generated an afterimage/pedestal ratio, $\left(N_{\text {ped }}+N_{\text {null }} \times 0.5\right) \div P_{n}$, where $\mathrm{N}_{\text {ped }}$ is the number of pedestal seen trials, $\mathrm{N}_{\text {null }}$ is the number of perceptual null trials seen, and $\mathrm{P}_{\mathrm{n}}$ is the number of overall trials) for each pedestal contrast. We fitted Weibull psychometric functions of the following form:

$$
P F_{w}=\gamma+(1-\gamma-\lambda) \exp \left(-\left(\frac{x^{\beta}}{\alpha}\right)\right)
$$

where $\alpha=$ threshold, $\beta=$ slope using a Bayesian likelihood method with the Palamedes toolbox for MATLAB (RRID:SCR_006521, Prins and Kingdom, 2009), and we assessed the $95 \%$ confidence intervals returned from the posterior distributions for significance. We also formally tested for significant differences between psychometric functions using Monte Carlo simulations of the likelihood ratios for each fit (Prins and Kingdom, 2009). The natural range of this ratio is $0 \leftrightarrow 1$, but we relabel it to span $-0.5 \leftrightarrow 0.5$ so that the perceptual null is zero on the ordinate $(-0.5$ indicates afterimage always seen and 0.5 indicates pedestal always seen).

Measurement of afterimage duration. After adapting the subjects to the mean background luminance (0.5) of the display, we presented flashed discs of $3^{\circ}$ in diameter with luminance values of $0,0.2,0.4,0.6,0.8$, and 1 and exposure durations of $1,2,4$, and 8 seconds $(6 \times 4=24$ stimuli) at 1 of 6 random equidistant positions around the fixation point. Each stimulus appeared 10 times in a fully randomized method of constants sequence. After stimulus offset, subjects were asked to report when the afterimages disappeared with a button-press. We measured the time between the stimulus offset and subjects' reported time as the afterimage duration. One subject was excluded because the subject could not reliably hold fixation for the $8 \mathrm{~s}$ stimulus condition.

Measurement of afterimage masking time latency. Dark (luminance value: 0 ) and bright (luminance value: 1 ) discs with a diameter of $3^{\circ}$ were randomly presented for $8 \mathrm{~s}$ at 1 of 6 random equidistant positions around the fixation point. After the stimulus turned off, the subject had to report whether they perceived an afterimage before a variably delayed $(\Delta t=0$ $\leftrightarrow 0.6 \mathrm{~s}$ ) grating mask was presented at the same location for $1 \mathrm{~s}$. The threshold and slope were estimated for dark and bright afterimages using the Psi-marginal adaptive staircase method (Prins, 2013), using a Weibull psychometric function holding the $\gamma$ parameter fixed at 0.5 for 50 trials. One subject was excluded because they could not reliably hold fixation for the $8 \mathrm{~s}$ stimulus condition.

Electrophysiology: animal preparation. All experimental procedures were approved by the Animal Care and Use Committee of the Institute of Neuroscience and by the local ethical review committee of the Shanghai Institutes for Biological Sciences. The cats were obtained from the institutional breeding colony.

A total of 18 anesthetized (pentobarbital sodium) and paralyzed (gallamine triethiodide) adult cats $(2-4 \mathrm{~kg})$ were used and artificially ventilated so as to maintain end-tidal $\mathrm{CO}_{2}$ between $3.1 \%$ and $3.6 \%$. Body temperature was continuously monitored to maintain $\sim 38^{\circ} \mathrm{C}$. Atropine $(0.05 \%)$, gentamycin $(4 \%)$, and dexamethasone $(0.5 \%)$ were injected intramuscularly every $12 \mathrm{~h}$ to prevent secretion, infection, and brain edema, respectively. Ear canals and ear bars were coated with antiseptic lidocaine hydrochloride gel, and all incisions were treated with lidocaine. The pupils were dilated and accommodation paralyzed with topical application of atropine methonitrate $(2 \% \mathrm{w} / \mathrm{v})$ and phenylephrine hydrochloride $(2.5 \% \mathrm{w} / \mathrm{v})$. The eyes were protected with contact lenses and correction lenses were inserted when necessary. Artificial pupils were placed in front of both eyes. Eyes were regularly checked and cleaned as necessary throughout the experiment. The locations of the optic disk and fovea were plotted using a reversible ophthalmoscope.

Electrophysiological recordings and visual stimuli. Craniotomy and duratomy were performed at Horsley-Clarke coordinates A6, L8. Singleunit recordings were made in dLGN using tungsten-in-glass electrodes (1-3 $\mathrm{M} \Omega$ ). Data were collected and stored by Axon CNS Multiclamp $700 \mathrm{~B}$ and Axon CNS Digitata 1440A. Neurons were recorded from layers A and A1 of the dLGN. S-potentials were manually sorted via Plexon Offline Sorter software. Stimulus generation, presentation, and data acquisition were controlled by a personal computer running MATLAB. Stimuli were presented on a HP P1230 CRT monitor that had a refresh rate of $85 \mathrm{~Hz}$. The luminance output of the CRT monitor was linearized using a corrected color lookup table generated by a ColorCAL colorimeter (Cambridge Research Systems). The luminance range of the screen was $0.1-68.5 \mathrm{~cd} / \mathrm{m}^{2}$. Luminance value and contrast of the visual stimulus were described by using the definition mentioned in the psychophysical experiment above.

The response types of $\mathrm{ON}$ and OFF center cells were determined by using a full-field flash. For each cell, the RF position and size were first estimated by hand mapping, and then precisely mapped by using $16 \times 16$ grid white noise stimulus refreshed at $85 \mathrm{~Hz}$.

For each dLGN cell, patches (diameter of $5^{\circ}$ ) of contrast reversing sinusoidal grating stimulus with 12 phases $\left(0^{\circ} \leftrightarrow 330^{\circ}\right.$ with $30^{\circ}$ steps in a randomized sequence) at the optimal and cutoff spatial frequency were used as a Null test to classify $\mathrm{X}$ and $\mathrm{Y}$ cells. In addition, along with the RF information (including potential shift effects) and transient/sustained firing response profile, the cell was classified as either X- or Y-type (Enroth-Cugell and Robson, 1966; Hochstein and Shapley, 1976; Derrington and Fuchs, 1979). For the main protocol, the background contrast was always 0 . At the onset of a stimulus, a flashed disc was presented over the center of the RF of each cell. The flashed disc was either dark (contrast -0.5 ) or bright (contrast 0.5 ). Stimuli were presented for a duration of $500 \mathrm{~ms}$ and followed by a $300 \mathrm{~ms}$ ( 38 of 175 cells) or $1000 \mathrm{~ms}$ ( 137 of 175 cells) blank (contrast 0 ) period. Each stimulus was presented 15 times in a random sequence. In some of the neurons, lower contrast stimuli (absolute value of 0.1 or 0.3 ) or stimuli with different durations 
$(0.3,1,2$, and $4 \mathrm{~s})$ were presented to test how contrast and duration influenced the cellular responses.

Measurement of response strength of $O N$ and OFF cells. A bright disc is a same-sign stimulus, and a dark disc is an opposite-sign stimulus for ON cells (and vice versa for OFF cells). As the visual stimuli used in the psychophysical experiment were $2^{\circ}$ and $3^{\circ}$ in diameter, in the electrophysiological recordings we tested dLGN cells responding to $2^{\circ}$ and $3^{\circ}$ stimuli. We plotted peristimulus time histograms (PSTHs, $50 \mathrm{~ms}$ boxcar and $1 \mathrm{~ms}$ shift for each step) of each cell responding to same-sign stimulus and opposite-sign stimulus separately. Only cells that were presented with a $1000 \mathrm{~ms}$ blank (137 of 175) were used to plot average PSTHs for ON and OFF cells. To statistically analyze response strength of each dLGN cell corresponding to same-sign stimulus onset, we calculated average spike rate of each cell during the first $300 \mathrm{~ms}$ after stimulus onset. Similarly, to analyze response strength of each dLGN cell corresponding to the opposite-sign stimulus offset, we calculated average spike rate of each cell during the first $300 \mathrm{~ms}$ after the stimulus was turned off. We pooled the two groups (300 and 1000 ms poststimulus blank) of cells together in the statistical analysis.

To measure the relative response strength of each cell to the oppositesign stimulus offset, we directly quantified the firing rate ratio between the response to stimulus offset and response to stimulus onset for each cell. Second, we used two lower-contrast stimuli $( \pm 0.1$ and \pm 0.3$)$ to plot and fit (using a spline) the contrast response function of $\mathrm{ON}$ and OFF cells. To quantitatively measure the inhibitory influence of opposite-sign stimuli on dLGN cells, we calculated the inhibitory effect using a simple measurement: baseline firing rate subtracting inhibitory period firing rate. Here, baseline is the spontaneous firing rate of dLGN cells presented with the background luminance alone.

Measurement of temporal dynamics of $\mathrm{ON}$ and OFF cells. To quantitatively measure the response latency of each cell, we used a standard 3 SD method (Tamura and Tanaka, 2001). Specifically, the time bin after the stimulus onset/offset at which the PSTH curve first crossed the baseline 3 SD line (the PSTH had to then contain at least 5 successive bins over the 3 SD line), was defined as the response latency of the neuron. For the response to the stimulus onset, baseline is defined as the spontaneous firing rate to the background luminance; whereas for the response to the stimulus offset, baseline is defined as the average firing rate of the last 300 ms of the inhibitory period. To show the response dynamics of dLGN cells, we divide the first $50 \mathrm{~ms}$ of the spike train of each dLGN cell with a $5 \mathrm{~ms}$ time window, and divide the second $70 \mathrm{~ms}$ with a $10 \mathrm{~ms}$ time window. In this way, we could observe the temporal progression of the $\mathrm{ON}$ and OFF channel asymmetry with more detail.

\section{Results}

\section{Perceptual asymmetries for bright and dark afterimages}

We first compared in eight human observers the perceptual strength of afterimages elicited by dark and bright $3^{\circ}$ discs presented at one of six equidistant $\left(3^{\circ}\right)$ positions around the fixation point. To measure the strength of the afterimage, we presented a variable-contrast pedestal of the same size and position immediately after the stimulus turned off for $400 \mathrm{~ms}$ before a mask was shown (Fig. 2A). If the pedestal contrast matches the perceived strength of the afterimage then there should be a cancellation or nulling of perception (neither the pedestal nor the afterimage are perceived, only the homogenous mean background luminance). If the subject did perceive a stimulus between the stimulus turning off and the mask turning on, they had to report whether it was darker or brighter than the background luminance. For dark stimuli, a dark poststimulus perception signified sensation of the same-sign pedestal, whereas a bright perception signified sensation of an afterimage (and vice versa for bright stimuli). We constructed an afterimage-to-pedestal seen index: -0.5 indicates afterimage always seen, 0 indicates the perceptual null, and 0.5 indicates pedestal always seen. We found that across eight subjects bright afterimages produced by dark stimuli required a higher pedestal contrast to generate the perceptual null and were thus perceived with higher contrast than dark afterimages produced by bright stimuli (Fig. $2 C$, inset, box plot; average dark stimulus cancellation pedestal $=0.136 \pm 0.02$, bright stimulus cancellation pedestal $=0.077 \pm 0.013 ; p=0.0078$ Wilcoxon signed rank). Because the largest differences occurred for the low pedestal contrast range in which afterimages were more likely to be perceived, we also measured the numerical integration of the area under the curve for the $-0.5 \leftrightarrow 0$ ratio range (Fig. $2 B, C$, shaded areas). We again found a statistically significant increase for dark-stimulus-induced bright afterimages compared with bright-stimulus-induced dark afterimages (dark stimulus area: $0.052 \pm 0.009$, bright stimulus area: $0.013 \pm 0.004 ; p=0.008$ Wilcoxon signed rank). The fitted psychometric functions to the combined subject data were statistically different (Fig. 2C; $p<$ $1 \times 10^{-12}$, Monte Carlo simulated likelihood test), with both the $\alpha$-threshold parameter significantly higher for bright afterimages compared with dark afterimages $(0.192 \pm 0.007$ vs $0.16 \pm 0.01$; $p=0.006$, Monte Carlo simulated likelihood test), and also the $\beta$-slope values ( $1.49 \pm 0.03$ vs $0.92 \pm 0.05 ; p=0.002$, Monte Carlo simulated likelihood test).

We also tested whether increasing the contrast and duration of the inducing stimulus significantly increased the duration that the afterimage was perceived (Fig. $2 D, E$ ). Overall, there were statistically significant effects for both stimulus duration and stimulus contrast and their interaction on the perceived duration of afterimages (stimulus duration $p=8.37 \times 10^{-79}$, stimulus contrast $p=3.66 \times 10^{-19}$, interaction $p=2.43 \times 10^{-9} ; \mathrm{N}$-way ANOVA). When comparing these effects for bright and dark afterimages, the effects were again more pronounced for bright afterimages (curves to the left) than dark afterimages (curves to the right). For the $8 \mathrm{~s}$ stimulus duration, we found that the difference between dark and bright afterimages at \pm 0.5 stimulus contrast was highly different statistically (Fig. $2 E$, filled circle, $p=$ $3.69 \times 10^{-7}$; post hoc Tukey-Kramer correction; we also found the difference at \pm 0.5 contrast was significant for $4 \mathrm{~s}$ stimulus duration, Fig. $2 E$, filled triangle, $p=0.0018$ ).

We finally attempted to determine whether there was any difference in sensitivity for bright and dark afterimages to a backward mask of varying delay. The inducing stimulus of \pm 0.5 contrast was presented for $8 \mathrm{~s}$. After the inducing stimulus was turned off, the subject had to report whether an afterimage was perceived or not before a mask $(\Delta t=0 \leftrightarrow 600 \mathrm{~ms}$ ) turned on (Fig. $2 F$ ). We used a Psi-marginal adaptive staircase method (Prins, 2013) to estimate the psychometric threshold and slope. For all 7 subjects ( 1 subject was excluded as he could not reliably maintain fixation without blinking for $8 \mathrm{~s}$ ), their perceptual thresholds were consistently shorter for bright afterimages compared with dark afterimages (Fig. $2 G$, top axis). We also generated the estimated psychometric functions from the adaptive staircase for each subject and found that the population threshold was statistically different (Fig. 2G, bottom axis; bright afterimage $=0.12 \pm$ $0.02 \mathrm{~s}$, dark afterimage $=0.31 \pm 0.03 \mathrm{~s} ; p=0.016$ Wilcoxon signed rank).

The asymmetry between dark and bright afterimages with respect to strength and duration parallels the threshold asymmetry for dark versus bright stimuli (Blackwell, 1946; Herrick, 1956; Short, 1966; Whittle, 1986; Chubb and Nam, 2000). Summarizing the psychophysical data, we found that bright afterimages elicited by dark stimuli exhibited greater strength, longer perceived duration, and were more robust to the effects of backward masking at short mask latencies. 
A
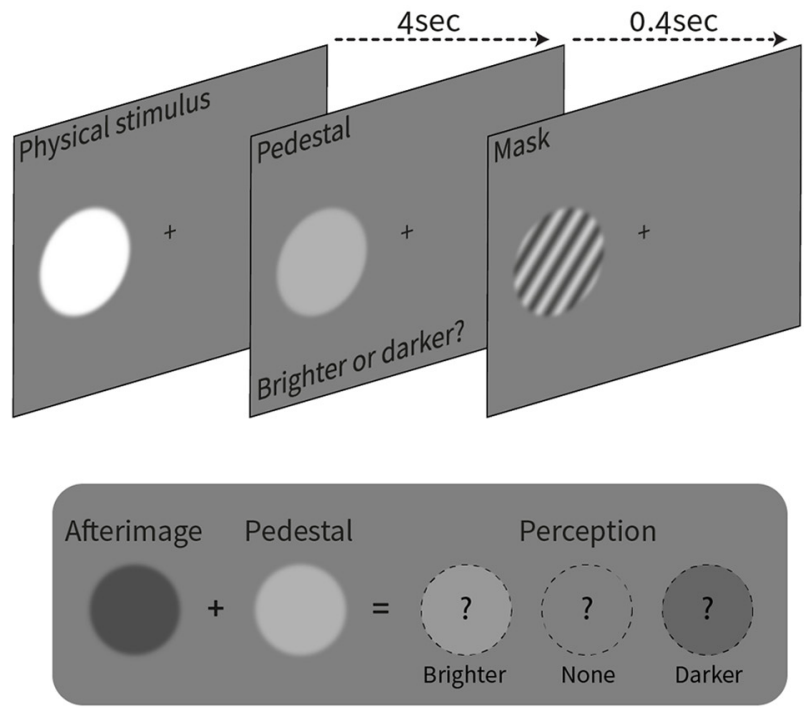

D

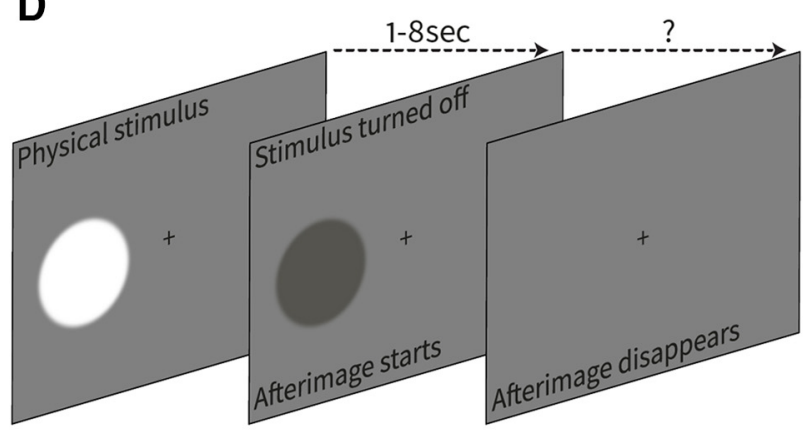

$\mathbf{F}$

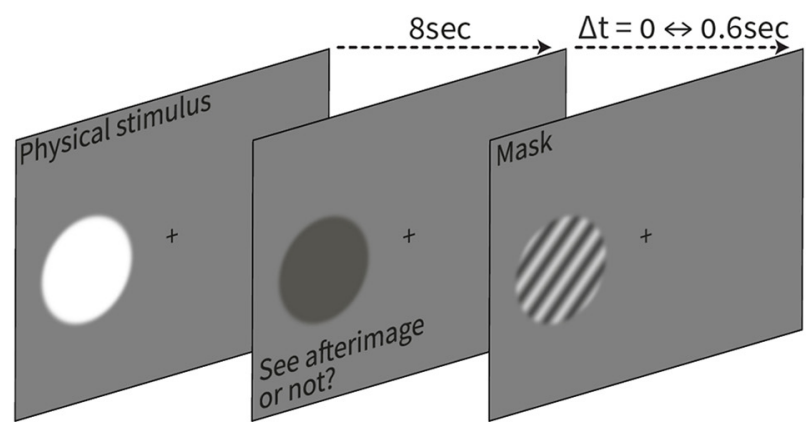

B
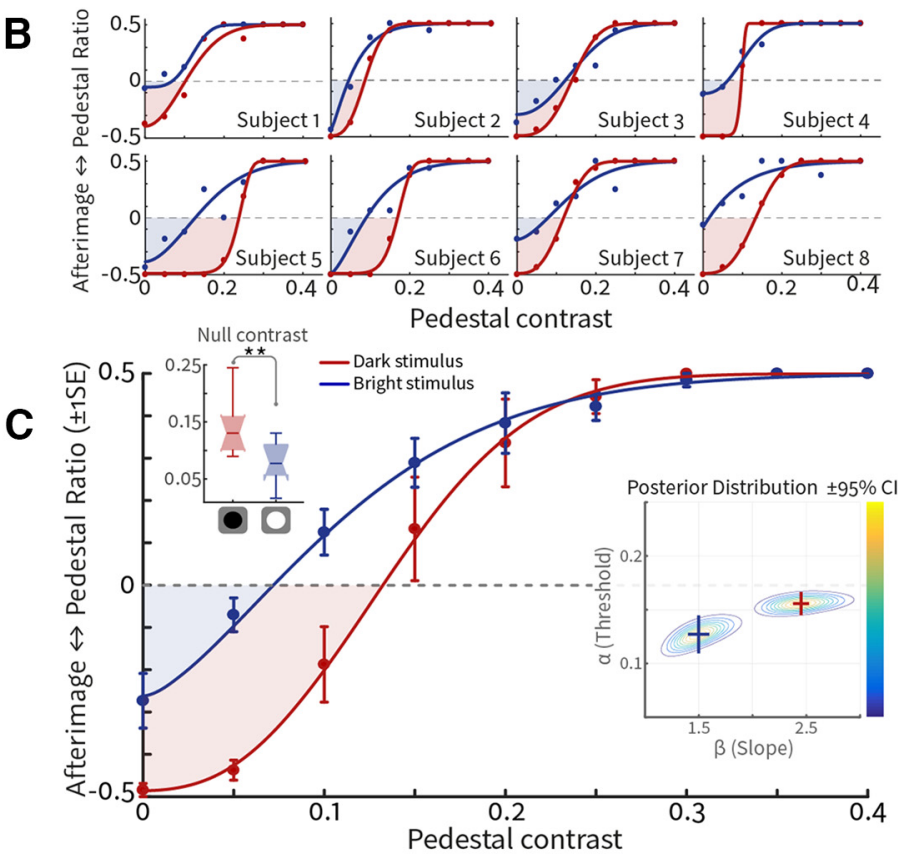

E

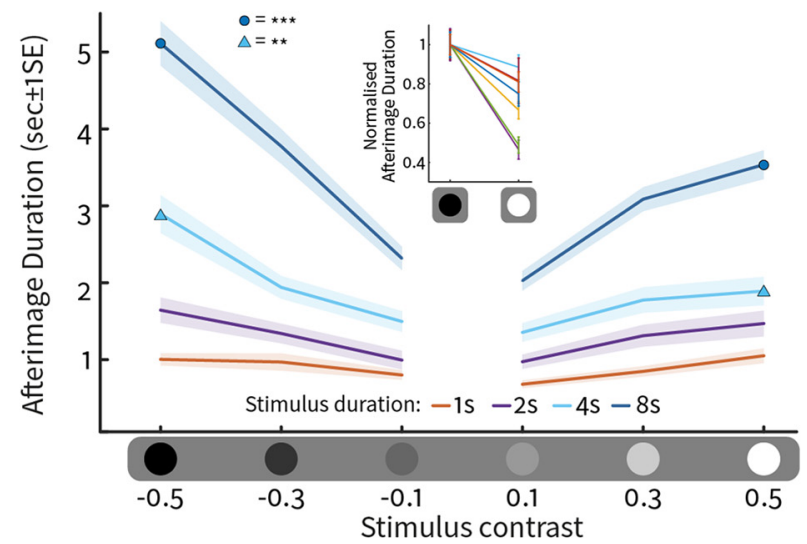

G

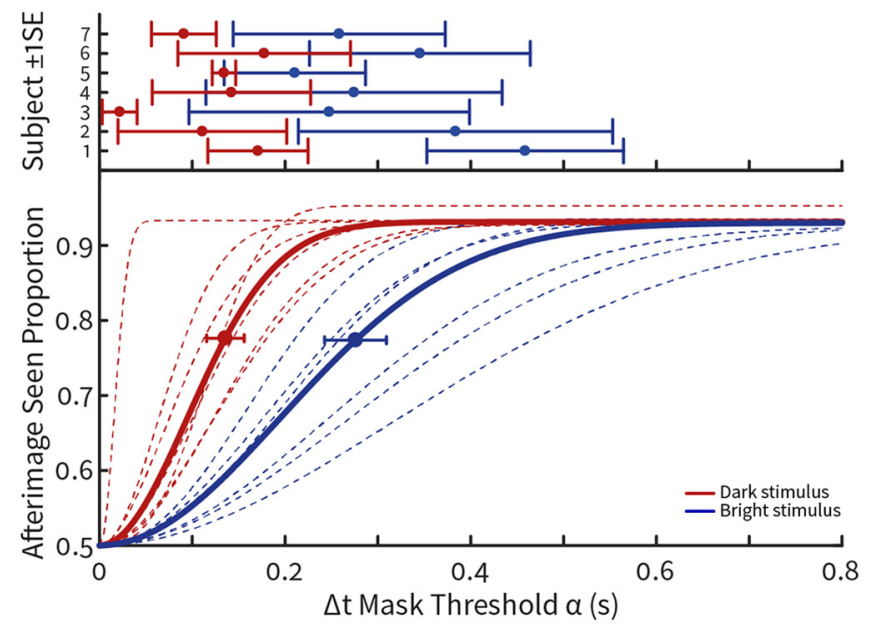

Figure 2. Asymmetry in perceived contrast and duration of negative afterimages elicited by bright and dark stimuli. $\boldsymbol{A}$, Paradigm for measuring the perceived contrast of afterimages (see Materials and Methods). $\boldsymbol{B}$, Afterimage $\leftrightarrow$ pedestal ratio for 8 subjects. Weibull psychometric functions were fitted for each curve. Shaded area represents the area under the curve for the probability of seeing dark versus bright afterimages. C, Population plot of Afterimage $\leftrightarrow$ pedestal ratio, \pm 1 SE $=1$ SEM. Top left, Inset, Statistical comparison of bright and dark afterimages for zero crossing. Bottom right, Inset, Bayesian estimated fitted posterior distribution and $95 \%$ confidence intervals for the psychometric threshold and slope. $\boldsymbol{D}$, Experimental paradigm for measuring afterimage duration (see Materials and Methods). E, Afterimage duration as a function of stimulus contrast for four stimulus durations. Inset, Afterimage duration for $8 \mathrm{~s} \mathrm{stimulus} \mathrm{presentation} \mathrm{for} 7 \mathrm{subjects;}$ values are normalized by the mean value of the bright afterimage. $\boldsymbol{F}$, Experimental paradigm for measuring afterimage sensitivity to mask latency (see Materials and Methods). $\boldsymbol{G}$, The threshold was estimated for dark and bright afterimages using the Psi-marginal adaptive staircase method. Top axis, Plot of the $\Delta t$ mask thresholds ( $\alpha \pm 1$ SE) for each subject. Bottom axis, Plot of the individual psychometric functions (dashed lines) and the population psychometric function (solid lines) for dark and bright stimuli. ${ }^{* *} p<0.01,{ }^{* *} p<0.001$. 

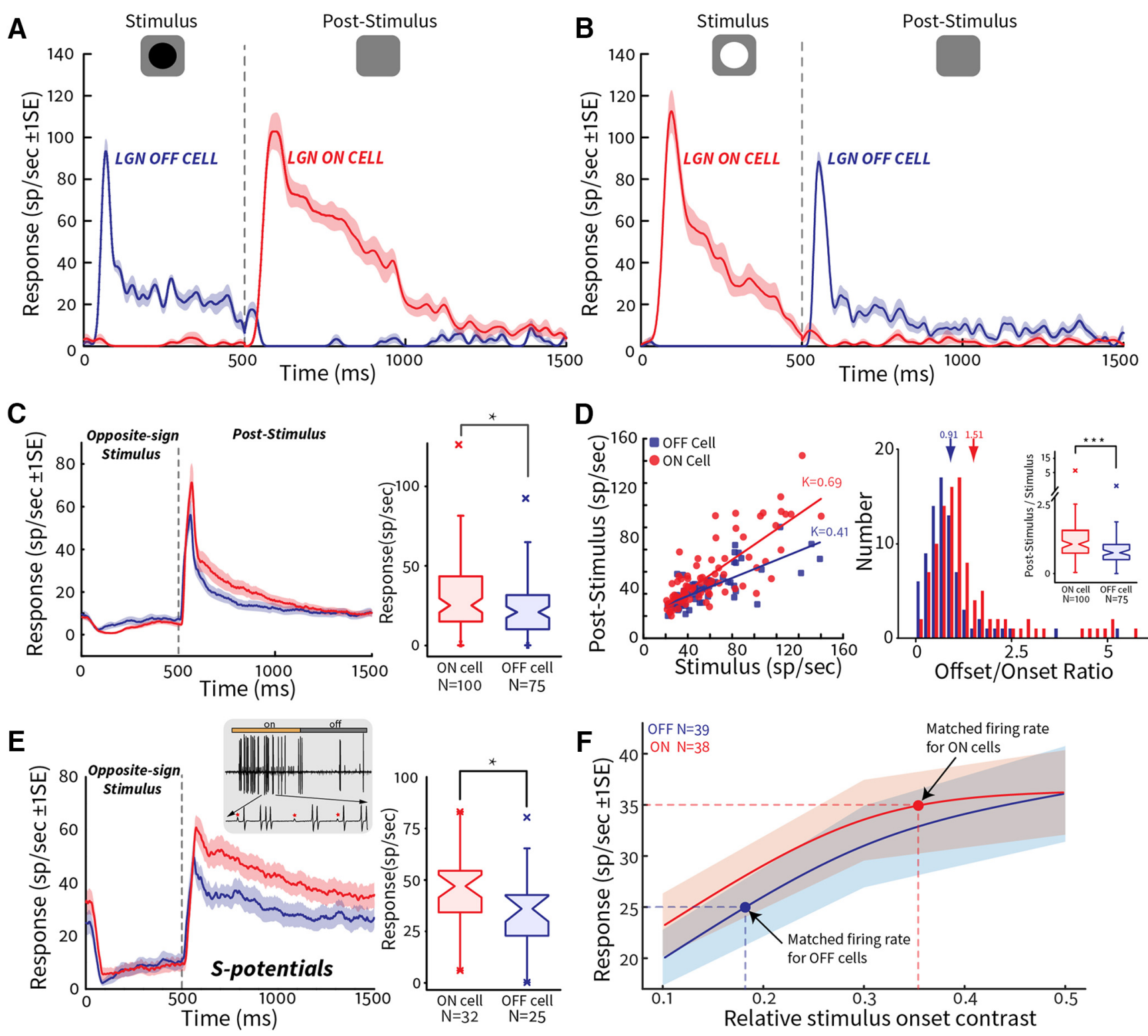

Figure 3. Poststimulus response strength is larger for ON cells than for OFF cells. $A$, Example $0 \mathrm{FF}$ and $\mathrm{ON}$ cell responses to a dark stimulus onset and offset. Blue represents $0 \mathrm{FF}$. Red represents $\mathrm{ON}$. $\mathrm{sp} / \mathrm{sec}$, Spikes per second. $\boldsymbol{B}$, The same cells responding to bright stimulus onset and offset. $C$, Left, Averaged PSTH to the offset of a bright stimulus for OFF cells and the offset of a dark stimulus for ON cells. Right, Box plots of the average $(300 \mathrm{~ms})$ firing rate following stimulus offset for OFF and ON cells. D, Left, Scatter plot for OFF (blue) and ON (red) cell responses. Ordinate, Poststimulus offset response to an opposite sign stimulus. Abscissa, Response to a stimulus of same sign. K, Slope of the regression line. Right, Histogram of offset/onset response of ON and Off cells. Inset, Box plots represent the comparison of relative response strength to the stimulus offset between $0 \mathrm{FF}$ cells and $0 \mathrm{~N}$ cells. Relative response strength is calculated as firing rate to the stimulus offset divided by the firing rate to the stimulus onset. $\boldsymbol{E}$, Left, Poststimulus PSTH derived from S-potentials. Inset, Example S-potentials recorded alongside the dLGN spike trains. Onset and offset responses of S-potentials are synchronized with dLGN spikes. Right, Box plots of the average ( $300 \mathrm{~ms}$ ) firing rate following stimulus offset for $0 \mathrm{FF}$ and $0 \mathrm{~N}$ units. $\boldsymbol{F}$, Stimulus onset response curves plotted as a function of stimulus contrast. Dashed line intersections overlay the equivalent firing rate of the mean offset responses in C. OFF cell's mean offset response is equivalent to a 0.18 contrast stimulus onset response. $0 \mathrm{~N}$ cell's mean offset response is equivalent to a 0.36 contrast stimulus onset response. ${ }^{*} p<0.05 .{ }^{* * *} p<0.001$.

\section{Stronger poststimulus response for ON compared with OFF cells}

The removal of opposite-sign stimuli elicits robust responses for neurons in the retina and dLGN of the cat (Singer and Creutzfeldt, 1970; Krüger and Fischer, 1975; Schiller, 1982, 1995). This has prompted researchers to suggest that the poststimulus responses of the retina or dLGN are the neural basis of the afterimage (Jung, 1973; Schiller and Dolan, 1994; Schiller, 1995; Schiller and Tehovnik, 2008). We therefore tested whether the poststimulus responses of $\mathrm{ON}$ and OFF cells elicited by dark and bright stimuli were asymmetrical in cat dLGN; and if so, whether the asymmetry would parallel those that we had obtained psychophysically. Dark or bright $2^{\circ}$ diameter discs were presented for $500 \mathrm{~ms}$. Stimulus luminance was either 0 or 1 , and background luminance was 0.5 (for details, see Materials and Methods). All stimuli presented were centered on the RF of dLGN cells. Figure $3 A, B$ shows example PSTHs to dark and bright stimuli in ON and OFF cells plotted as a function of time. For a dark disc stimulus, OFF cells were activated at the stimulus onset, whereas ON cells were activated at the stimulus offset (Fig. $3 A$ ). Conversely, when a bright disc was presented, $\mathrm{ON}$ cells were activated at the stimulus onset, whereas OFF cells were activated at the stimulus offset (Fig. $3 B$ ). Across the population, the offset of a dark stimulus elicited stronger poststimulus responses in ON cells than that of OFF cells to 
the offset of a contrast-matched bright stimulus (Fig. 3C). Statistically, the average firing rate of $\mathrm{ON}$ cells to an opposite-sign stimulus offset was higher than that of OFF cells ( 100 ON cells: $35.6 \pm 3.2 \mathrm{sp} / \mathrm{s}, 75$ OFF cells: $25.2 \pm 2.3 \mathrm{sp} / \mathrm{s} ; p=0.04$, Wilcoxon rank sum). However, ON and OFF cells show no such differences responding to the same-sign stimulus onset (100 ON cells: $35.28 \pm 3.53 \mathrm{sp} / \mathrm{s}, 75$ OFF cells: $36.17 \pm 3.44 \mathrm{sp} / \mathrm{s}, p=0.8$, Wilcoxon rank sum). We also measured the offset responses to the preferred stimulus, as although dLGN cells are initially suppressed, they can exhibit a postinhibitory rebound to the offset of the preferred stimulus (Nelson, 1991). There was no statistical difference in the preferred-stimulus offset response amplitude between ON and OFF cells (100 ON cells: $9.9 \pm 1.4$ sp/s, 75 OFF cells: $10.4 \pm 1.2 \mathrm{sp} / \mathrm{s} ; p=0.7$ Wilcoxon rank sum).

Figure $3 D$ plots the responses of $\mathrm{ON}$ and OFF cells to the onset of a same-sign stimulus against the offset of an opposite-sign stimulus. The steeper slope for $\mathrm{ON}$ cells indicates that the relative strength of the poststimulus response is higher for $\mathrm{ON}$ cells than for OFF cells (Fig. 3D, left). The histogram (Fig. 3D, right) also show the different distributions of offset/onset response ratios of $\mathrm{ON}$ and OFF cells. The resultant ratio in firing rate between stimulus offset to stimulus onset is statistically higher for ON cells than for OFF cells ( $1.51 \pm 0.18$ for ON cells, $0.91 \pm 0.09$ for OFF cells; $p=7.2 \times 10^{-5}$, Wilcoxon rank sum). When we look at the initial segment of the curve of the average PSTH in Figure 3C (the first $500 \mathrm{~ms}$ ), the dark stimulus depresses ON cells (the red curve) more than the bright stimulus depresses OFF cells (the blue curve). There is evidence suggesting that stronger inhibition triggers a higher rebound (Grenier et al., 1998; Wang et al., 2016), and this seems to be the case here (comparing the red and blue curves for the offset responses in Fig. 3C). Stronger inhibition of ON cells by a dark disc may lead to a stronger poststimulus response consistent with a stronger negative afterimage. Overall, the stronger poststimulus responses for ON cells are consistent with our psychophysical observation that dark stimuli elicit stronger afterimages (Fig. 2B,C).

Because the ON and OFF streams and asymmetries start in the retina, one might ask whether differences similar to those found in dLGN exist in ON and OFF RGCs. To answer this question, we analyzed the offset responses from the spike-sorted S-potentials taken from the dLGN recordings (Fig. 3E, inset). S-potentials have a low amplitude, a long time constant, and are thought to be EPSPs from RGCs (Bishop et al., 1958, 1962; Hubel and Wiesel, 1961; Cleland et al., 1971; Lee et al., 1983; Kaplan and Shapley, 1984; Sincich et al., 2007). As expected, we found asymmetries in RGCs similar to those in dLGN. The poststimulus firing rate for ON cells is higher than that for OFF cells ( 34 ON cells: $44.96 \pm$ $3.08 \mathrm{sp} / \mathrm{s}$ vs 25 OFF cells: $35.07 \pm 3.85 \mathrm{sp} / \mathrm{s} ; p=0.018$, Wilcoxon rank sum; Fig. 3E). In the psychophysical matching experiment, we quantified the brightness and darkness of a negative afterimage through perceptual nulling (Fig. $2 A-C$ ). For the dLGN recordings, we can use the contrasts of onset responses as an index to represent poststimulus responses whereby the onset and offset responses have corresponding firing rates. Figure $3 F$ plots the onset response strength of ON cells $(N=38)$ and OFF cells $(N=$ 39) as a function of a range of stimulus contrasts (with 0.1, 0.3, and 0.5 luminance increments and decrements for $\mathrm{ON}$ cells and OFF cells, respectively). The stimulus contrasts of the onset responses for ON and OFF cells, which generated equivalent firing rates to the mean poststimulus responses at 0.5 contrast, were 0.36 and 0.18 , respectively. These results support a notion that the poststimulus response of $\mathrm{ON}$ cells to a dark stimulus is stron- ger than that of OFF cells to a bright stimulus, and mirrors the psychophysical results.

In summary, the neurophysiological offset asymmetry in dLGN and putative RGC cells is consistent with our psychophysical data showing that afterimages elicited by dark stimuli (presumably initiated from offset responses of ON cells) are perceived as stronger than afterimages elicited by bright stimuli.

\section{Long stimulus duration predominantly affects dLGN ON cells} One established feature of afterimage phenomenology and a clear finding from our perceptual afterimage data (Fig. 2E) was the effect of stimulus duration: longer stimulus durations enhanced the duration of the afterimage and the differential between dark and bright afterimages. The neurophysiological data presented so far have used a short duration stimulus presentations (500 ms). For a subset of the data we also collected offset responses to different stimulus duration (300, 1000, 2000, and $4000 \mathrm{~ms})$. Population PSTHs for dLGN cells are shown in Figure 4, partitioned into a comparison of shortest (300 ms) versus longest (4000 ms) stimulation duration for ON cells and OFF cells (Fig. 4A), and comparing ON versus OFF cells at each stimulation duration (Fig. $4 B$ ). We observed that the poststimulus response difference for stimulus duration was more pronounced in ON cells than OFF cells (Fig. 4A). We quantified the final $300 \mathrm{~ms}$ of the response and found it was statistically different for ON cells (7.31 \pm $1.17 \mathrm{~s} / \mathrm{s}$ vs $13.4 \pm 2.71 \mathrm{~s} / \mathrm{s} ; N=44$ for $300 \mathrm{~ms}$ stimulus and $N=45$ for $4000 \mathrm{~ms}$ stimulus, $p=0.04$ Wilcoxon rank sum), but not for OFF cells $(9.85 \pm 2.26 \mathrm{~s} / \mathrm{s}$ vs $8.63 \pm 2.15 \mathrm{~s} / \mathrm{s} ; N=28$ for $300 \mathrm{~ms}$ stimulus and $N=31$ for $4000 \mathrm{~ms}$ stimulus, $p=0.48$ Wilcoxon rank sum). This resulted in an increasing differential between $\mathrm{ON}$ versus OFF cells with increasing stimulus duration (Fig. 4B, comparing stimulus durations of $300,1000,2000$, and $4000 \mathrm{~ms}$ ). Analyzing the final $300 \mathrm{~ms}$ of the response plateau, we found that only the $4000 \mathrm{~ms}$ curves were different statistically ( $45 \mathrm{ON}$ cells: $13.4 \pm 2.7 \mathrm{~s} / \mathrm{s}, 31$ OFF cells: $8.63 \pm 2.15 \mathrm{~s} / \mathrm{s} ; p=0.01$ Wilcoxon rank sum). Interestingly, this difference between ON and OFF cell offset responses persisted even up to $4000 \mathrm{~ms}$ of poststimulus duration (Fig. 4B, inset, measuring 3000-4000 ms: ON cells $9.21 \pm 1.78 \mathrm{~s} / \mathrm{s}$, OFF cells: $6.43 \pm 1.77 \mathrm{~s} / \mathrm{s} ; p=0.001$, Wilcoxon rank sum). We also performed the same stimulus duration analysis on the S-potential responses (Fig. 4C). There were no statistical differences for short versus long stimulus presentation (Fig. $4 C$, top axes) or any differences at short or long stimulus presentations between $\mathrm{ON}$ and $\mathrm{OFF}$ cells (Fig. $4 \mathrm{C}$, bottom axes). Although part of the initial rebound response asymmetry could be driven by the compressive nonlinearity presumably coming from the photoreceptors (Kremkow et al., 2014), fast photoreceptor adaptation (Smith et al., 2008) should cause such a mechanism to only affect the very earliest part of the response. Our data show that in the dLGN, but not the presumptive retinal afferents, responses parallel the psychophysical results showing the asymmetry between the dark and bright stimuli becomes larger with increasing duration.

\section{Faster response to the offset of opposite-sign stimulus in OFF cells than in ON cells}

As previous researchers have reported latency differences between ON and OFF cell stimulus responses, we were also interested in the latency of the offset responses to opposite-sign stimuli. The PSTHs of the poststimulus responses for $\mathrm{ON}$ and OFF cells were averaged and normalized (Fig. 5A). OFF cells (blue curve) responded earlier to the removal of opposite-sign stimuli than ON cells. Results are summarized in the boxplot of 

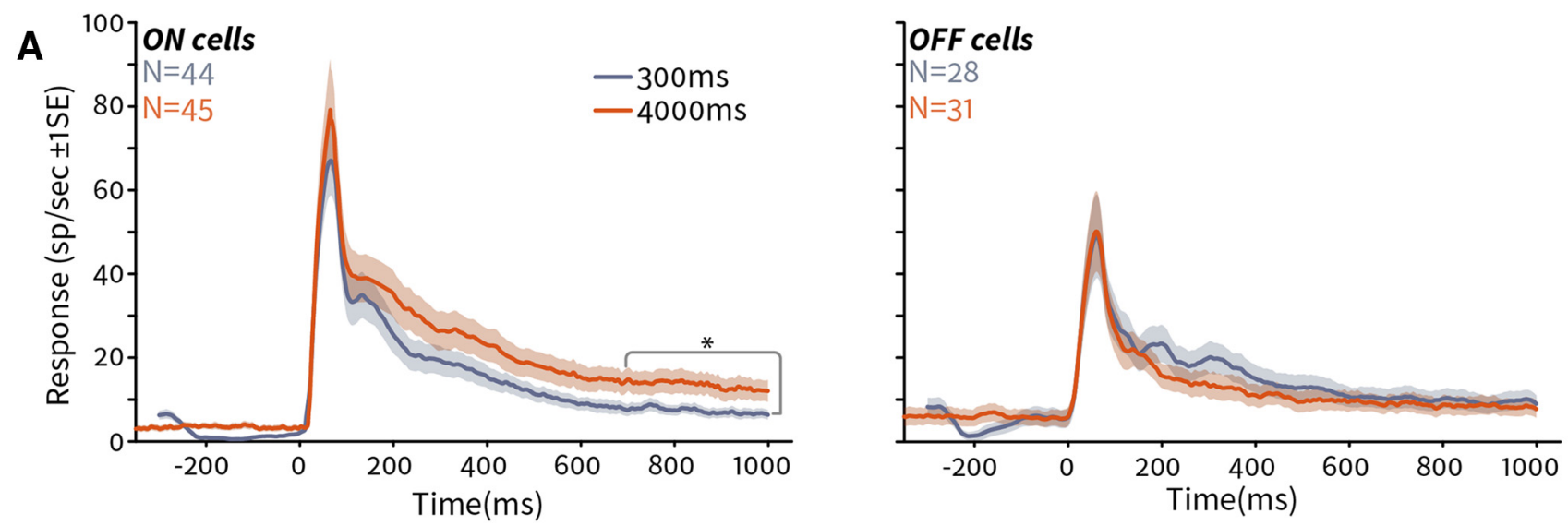

B
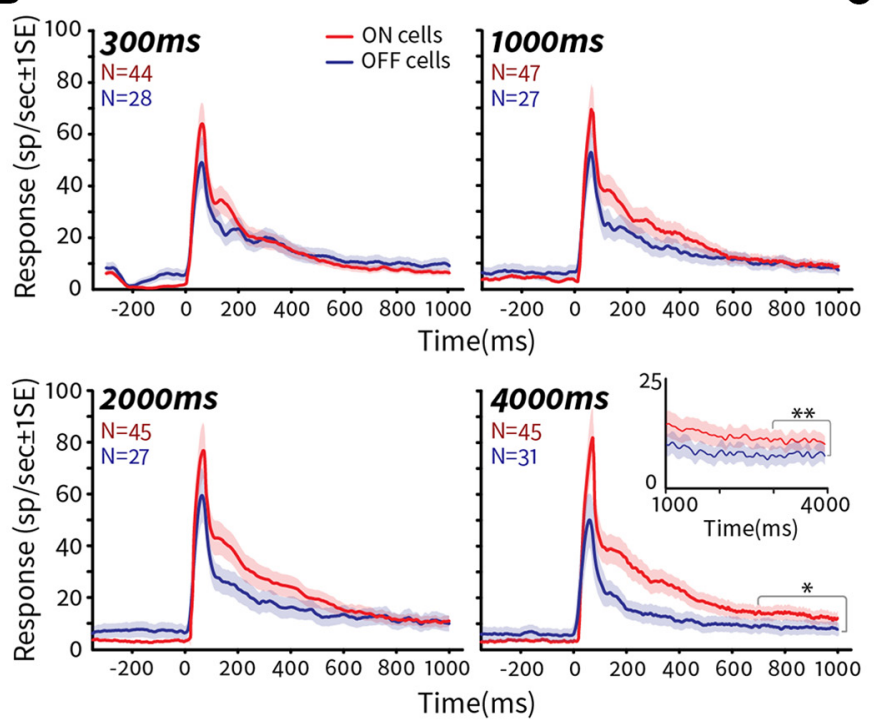

C
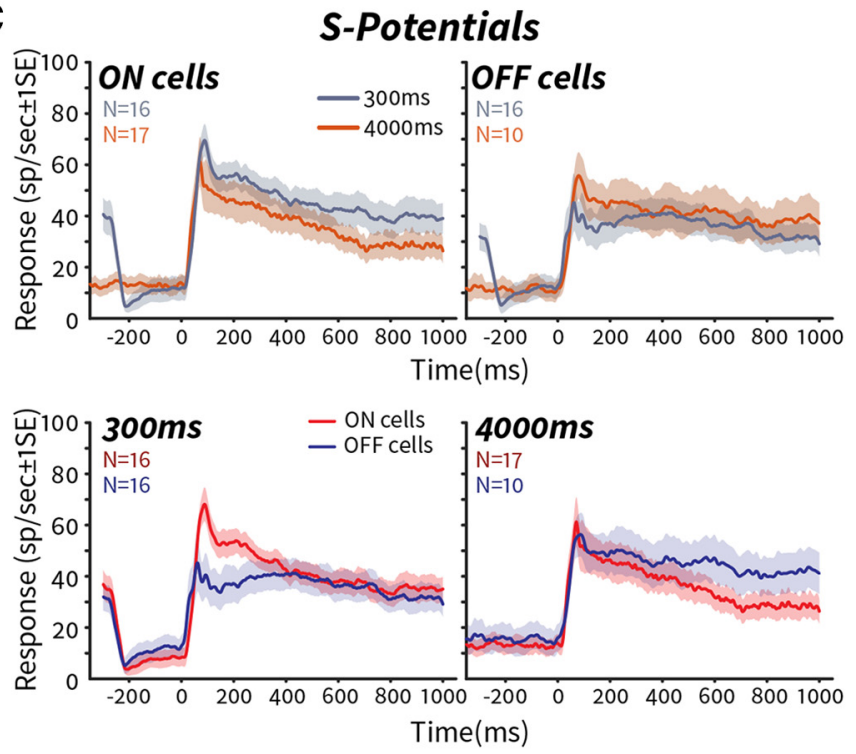

Figure 4. Stimulus duration has a greater influence on poststimulus responses for dLGN ON cells than for OFF cells. A, Population PSTH comparison of short ( $300 \mathrm{~ms}$, gray-blue) versus long ( 4000 $\mathrm{ms}$, orange) stimulus duration on poststimulus responses for ON (left) and OFF (right) cells. B, Population PSTH to 300, 1000, 2000, and 4000 ms of stimulus duration, comparing the offset responses of OFF cells (blue) versus $\mathrm{ON}$ cells (red) for each stimulus duration. Inset, Axis for $4000 \mathrm{~ms}$ stimulus duration shows the response from 1000 to $4000 \mathrm{~ms}$ of poststimulus time. C, S-potential responses, comparing short versus long stimulus duration for $\mathrm{ON}$ (top left) and OFF cells (top right), and comparing $0 \mathrm{~N}$ versus $0 \mathrm{FF}$ cells at short (lower left) and long (lower left) stimulus durations. ${ }^{*} p<0.05$, ${ }^{* *} p<0.01$.

Figure 5 A $(31.39 \pm 2.32 \mathrm{~ms} 66$ OFF cells vs $37.39 \pm 2.27 \mathrm{~ms} 95$ ON cells, $p=0.024$, Wilcoxon rank sum). To study the temporal dynamics of the poststimulus response of ON and OFF cells in greater detail, we recomputed the first $120 \mathrm{~ms}$ PSTH into a number of bins for statistical comparison (Fig. 5B, $p$ values are Bonferroni corrected for multiple comparisons). Within the first 40 $\mathrm{ms}$ response period, OFF cells fired statistically earlier than ON cells. When analyzing the S-potentials, the response latency shows the same pattern as for the dLGN cells, OFF cells exhibit shorter latency than ON cells ( 23 OFF cells $26.39 \pm 3.49 \mathrm{~ms}$ vs 31 ON cells $28.84 \pm 1.78 \mathrm{~ms}, p=0.03$, Wilcoxon rank sum; Fig. $5 C$ ). We also asked whether there were differences between the stimulus onset and stimulus offset latencies for ON and OFF cells. We found that $\mathrm{ON}$ and OFF cells show little latency difference when analyzing the stimulus onset (Fig. $5 D$; $52.55 \pm 3.08 \mathrm{~ms} 66 \mathrm{OFF}$ cells, $48.37 \pm 2.34 \mathrm{~ms} 95 \mathrm{ON}$ cells; $p=0.25$, Wilcoxon rank sum). However, we found that both ON and OFF dLGN cells responded faster to stimulus offset than to stimulus onset (Fig. $5 E$; OFF cells: $31.39 \pm 2.32 \mathrm{~ms}$ for the offset response vs $52.55 \pm 3.08 \mathrm{~ms}$ for the onset response; $p=3.1 \times 10^{-10}$, Wilcoxon signed rank; ON cells: $37.39 \pm 2.27 \mathrm{~s}$ for the offset response vs $48.37 \pm 2.34 \mathrm{~ms}$ for the onset response; $p=8.2 \times 10^{-6}$, Wilcoxon signed rank). This indicates that the mechanism underlying the poststimulus responses for opposite-sign stimuli is different from that underlying the onset excitatory responses to the same-sign stimuli, resulting in dLGN neurons responding faster to the stimulus offset.

$\mathrm{X}$ cells contribute mainly to the difference in strength and $\mathrm{Y}$ cells to the difference in latency

There are two kinds of cells in cat retina and dLGN, namely, X cells and Y cells (Enroth-Cugell and Robson, 1966; Shapley and Hochstein, 1975; Derrington and Fuchs, 1979; Lehmkuhle et al., 1980). X cells show a sustained response to the stimuli, whereas $Y$ cells respond transiently. $\mathrm{X}$ cells are considered more similar to parvocellular cells in the monkey retina and dLGN, whereas $Y$ cells are more similar to magnocellullar cells. Psychophysical experiments in human observers and neurophysiological experiments in monkey dLGN suggest that parvocellullar cells are more heavily involved in afterimage generation (Ingling and Grigsby, 1990; Kelly and Martinez-Uriegas, 1993; McLelland et al., 2009). Because of the similarity of X cells in cat with parvocellullar cells 

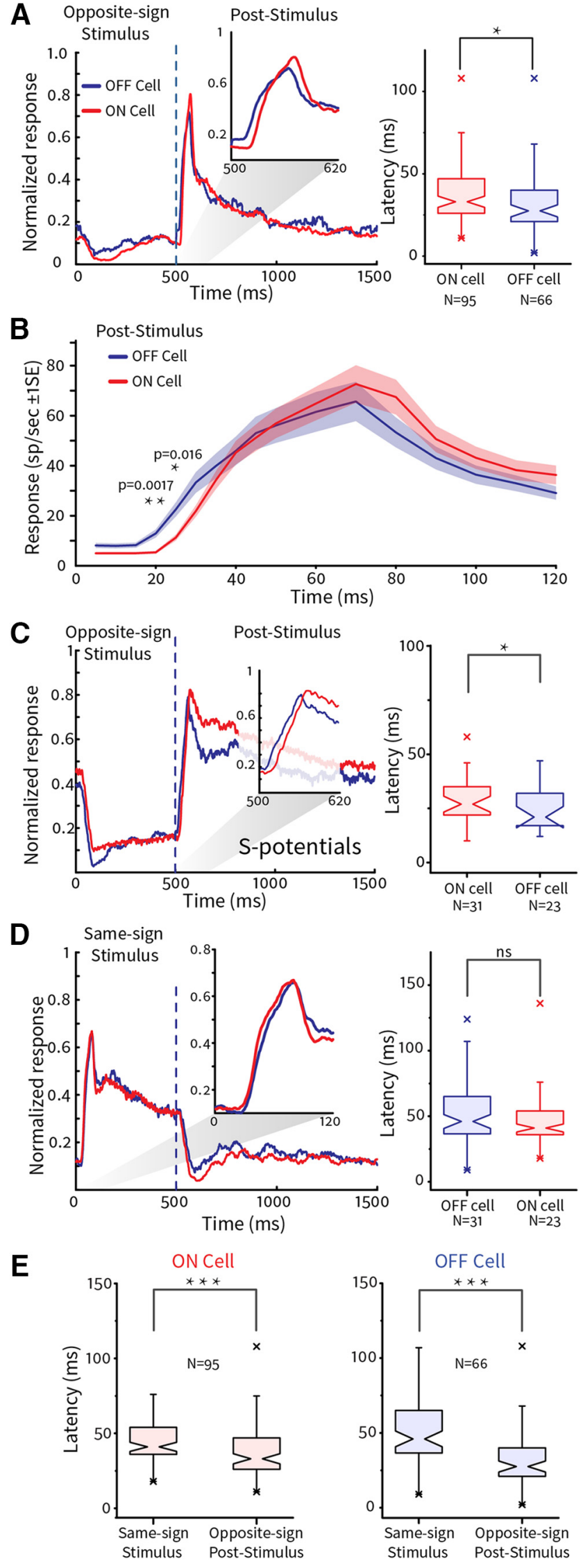

Figure 5. Poststimulus responses are faster for OFF cells than for ON cells. A, Left, Normalized PSTH to the offset of a bright stimulus for OFF cells and to the offset of a dark stimulus for ON cells. Inset, The first $120 \mathrm{~ms}$ of each response. Right, Box plot latency comparison between OFF in primate, we speculated that X cells contributed more heavily to the response asymmetries between $\mathrm{ON}$ and OFF cells in cat. As expected, we found that the asymmetry in response strength resides only in the X cells (Fig. 6A; 79 X-ON $33.22 \pm 3.74$ s/s, 52 $\mathrm{X}$-OFF $21.82 \pm 3.03 \mathrm{~s} / \mathrm{s}, p=0.003$, Wilcoxon rank sum), but not in the Y cells (Fig. $6 B$; $21 \mathrm{Y}$-ON $31.47 \pm 6.87 \mathrm{~s} / \mathrm{s}, 23 \mathrm{Y}$-OFF $33.50 \pm 6.99 \mathrm{~s} / \mathrm{s}, p=0.85$, Wilcoxon rank sum). On the other hand, Y cells show more latency asymmetry than X cells (Fig. $6 C, D$; $77 \mathrm{X}-\mathrm{ON} 36.86 \pm 2.57 \mathrm{~ms}, 46 \mathrm{X}$-OFF $32.09 \pm 2.93 \mathrm{~ms}, p=$ 0.11 , Wilcoxon rank sum; $18 \mathrm{Y}-\mathrm{ON} 39.67 \pm 4.87 \mathrm{~ms}, 20 \mathrm{Y}-\mathrm{OFF}$ $29.80 \pm 3.72 \mathrm{~ms}, p=0.039$, Wilcoxon rank sum).

Finally, we noted that in many cases the inhibition of ON cells during the presentation of the opposite-sign stimulus was greater in ON cells than OFF cells (e.g., Figs. 3C, 4B). To quantify this, we measured the inhibition compared with the baseline response to zero contrast. We found that there existed statistical differences in the inhibitory effects between $\mathrm{ON}$ and OFF cells across the population (Fig. $7 \mathrm{~B}$, right; $100 \mathrm{ON}$ cells $-5.65 \pm 1.04 \mathrm{~s} / \mathrm{s}, 75 \mathrm{OFF}$ cells $-1.43 \pm 0.75, p=0.017$, Wilcoxon rank sum). The population result was only consistent with the subpopulation responses of the $\mathrm{X}$ cells but not the $\mathrm{Y}$ cells (the middle and left panels,79 X-ON cells $-6.18 \pm 1.16 \mathrm{~s} / \mathrm{s}, 52 \mathrm{X}$-OFF cells $-1.33 \pm$ $1.05 \mathrm{~s} / \mathrm{s}, p=0.006$, Wilcoxon rank sum; $20 \mathrm{Y}-\mathrm{ON}$ cells $-1.99 \pm$ $1.73 \mathrm{~s} / \mathrm{s}, 23 \mathrm{Y}$-OFF cells $-1.66 \pm 0.71 \mathrm{~s} / \mathrm{s}, p=0.44$, Wilcoxon rank sum).

\section{Discussion}

Our psychophysical experiments revealed asymmetries for negative afterimages elicited by the removal of contrast-matched bright and dark discs with respect to perceived strength and duration. Specifically, dark stimulus discs produced stronger negative afterimages with a longer perceptual duration. At the neuronal level, we found that ON cells in cat retina and dLGN showed greater firing rates to the removal of dark discs than OFF cells to the removal of bright discs. When using longer stimulus durations, we found that only dLGN ON cells maintained an elevated firing rate during late part of the poststimulus response. Therefore, the asymmetries revealed in the subcortical neurophysiological recordings of poststimulus responses in cats paralleled the asymmetries of negative afterimages elicited by bright and dark stimuli in human subjects.

\section{Poststimulus response strength comparison between $\mathrm{ON}$ and OFF cells}

Consistent with previous work (Krüger and Fischer, 1975; Kremers et al., 1993; Benardete and Kaplan, 1999), we found that ON and OFF cell responses to same-sign stimuli of equal contrasts are not significantly different from each other, suggesting the excitatory inputs to ON and OFF cells driven by the same-sign stimuli are broadly equivalent. These same-sign findings suggest that subcortical ON or OFF channels are essentially equal and are consistent with previous findings showing that "black" dominance first appears in superficial layers of monkey V1 (layers 2/3),

and $\mathrm{ON}$ cells in response to stimulus offset. $\boldsymbol{B}$, Initial $120 \mathrm{~ms}$ responses time course of $\mathrm{ON}$ cells and OFF cells is divided into several smaller time windows. $p$ values are Bonferroni-corrected $t$ tests performed on each window. C, Left, Normalized S-potential poststimulus PSTH. Inset, The first $120 \mathrm{~ms}$ of each response. Right, Box plot latency comparison between OFF and ON cells in response to stimulus offset. $\boldsymbol{D}$, Legends as in $\boldsymbol{A}$ for $\mathrm{ON}$ and $\mathrm{OFF}$ cells responding to the stimulus onset. $\boldsymbol{E}$, Statistical comparison between response latencies of each dLGN cells responding to the stimulus onset and stimulus offset. Left, $0 \mathrm{~N}$ cells. Right, OFF cells. ${ }^{*} p<0.05,{ }^{* *} p<0.01$, ${ }^{* * *} p<0.001$. 

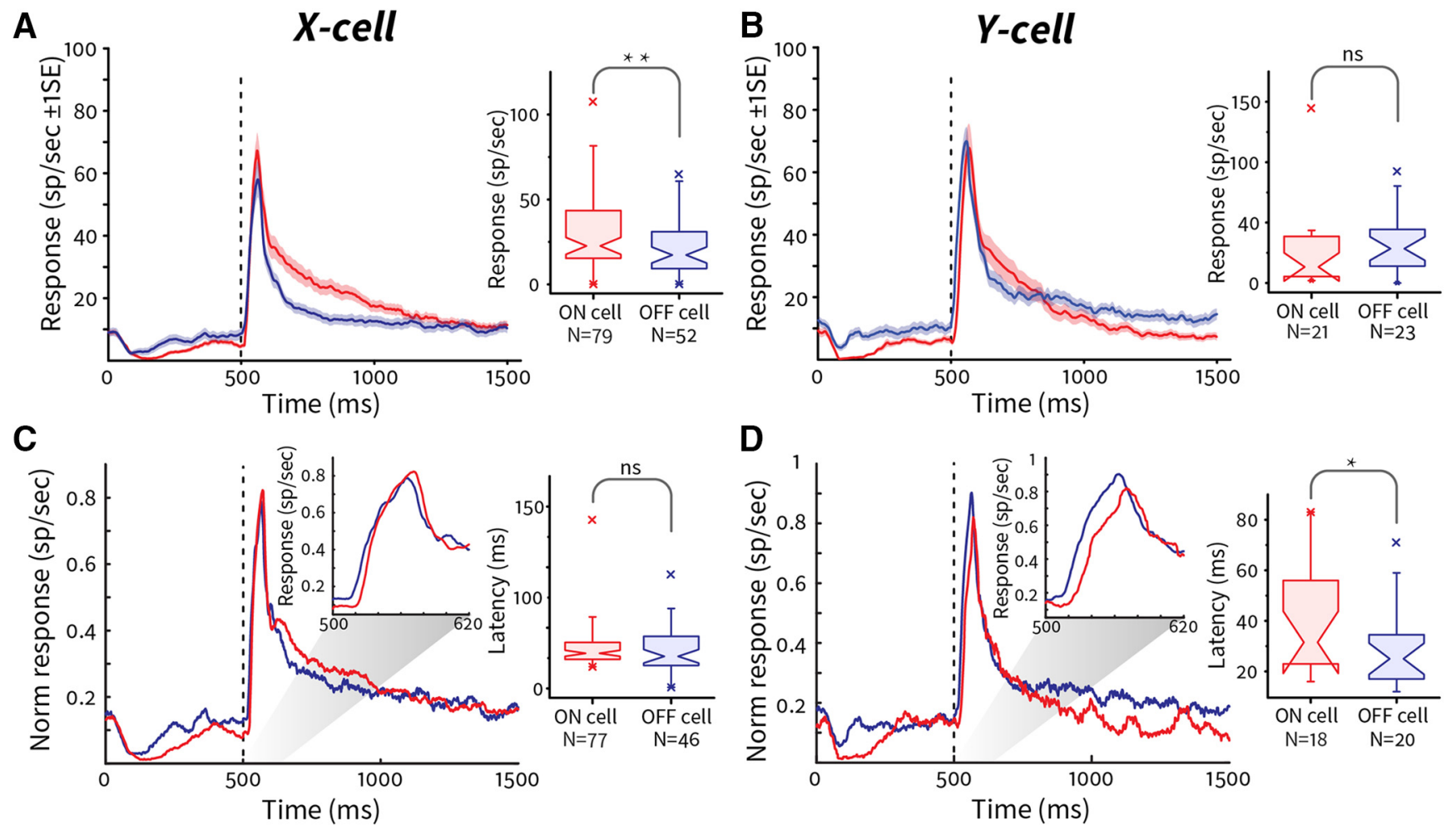

Figure 6. X cells contribute mainly to the strength difference, and Y cells contribute more to the latency difference. $\boldsymbol{A}$, Left, PSTH averaged over dLGNX-OFF cells (blue curve) to the offset of a bright stimulus and dLGN X-ON cells (red curve) to the offset of a dark stimulus. Right, Box plots showing the comparison of response strength between X-0FF cells and X-0N cells for stimulus offset. C, Left, Normalized PSTH for X-OFF cells to the removal of a bright spot (blue curve) and X-0N cells to the removal of a dark spot (red curve). Inset, The first $120 \mathrm{~ms}$ of each response. Right, Box plots showing the comparison of the latencies between X-OFF and X-ON cells in response to stimulus offset. $\boldsymbol{B}, \boldsymbol{D}$, Same legends as $\boldsymbol{A}, \boldsymbol{C}$ for $\mathrm{Y}$ cells. ${ }^{*} p<0.05$. ${ }^{* *} p<0.01$.
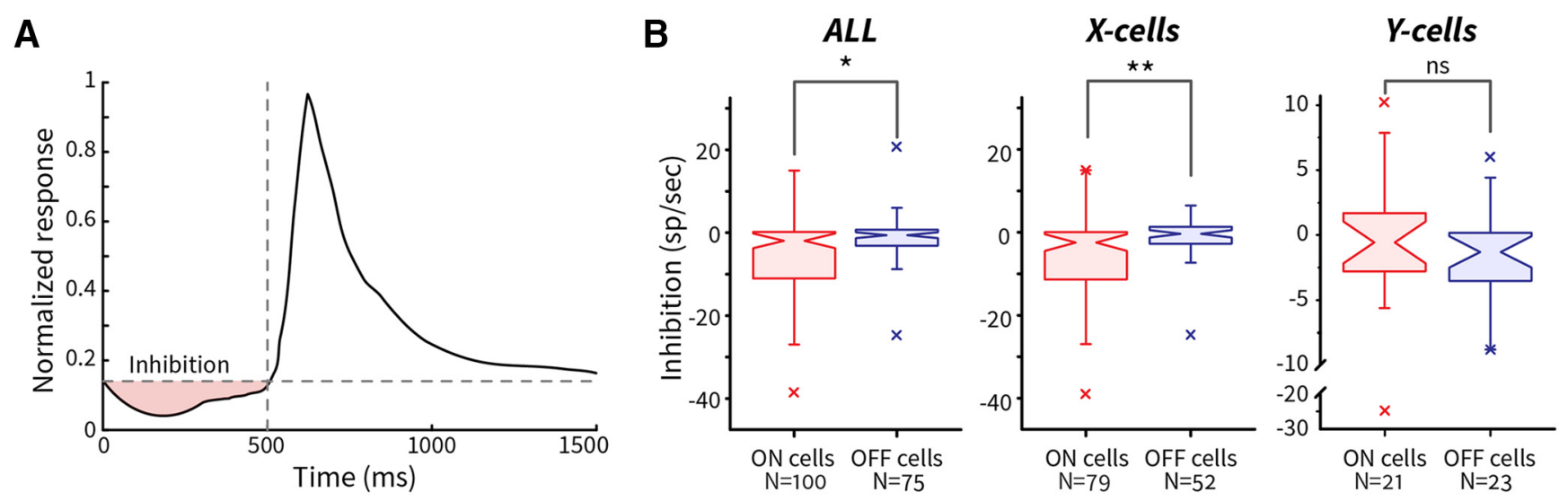

Figure 7. Inhibition elicited by opposite polarity stimulus is higher for $0 \mathrm{~N}$ cells than for OFF cells. $A$, Demonstration of the inhibitory effect of the opposite polarity stimulus. Dashed line indicates the baseline. Red shaded area represents the inhibitory effect. $\boldsymbol{B}$, Comparison of inhibitory effects exerted by opposite polarity stimulus. Inhibitory effect is calculated as follows: baseline spike rate spike rate elicited by opposite polarity stimulus. Left, All cells. Middle, X cells. Right, Y cells. ${ }^{*} p<0.05 .{ }^{* *} p<0.01$.

although there is no difference between ON and OFF channels in thalamo-recipient layer 4 (Jin et al., 2008; Yeh et al., 2009; Xing et al., 2010; Zurawel et al., 2014). However, for the offset of opposite-sign disc stimuli of equal contrasts, ON cells showed stronger poststimulus responses than OFF cells, exhibiting ONchannel dominance to the offset of opposite-sign stimuli. Consistent with previous studies (Zaghloul et al., 2003; Jin et al., 2011), we found that dark discs produce stronger inhibition in ON cells than bright discs to OFF cells. Neurons in the thalamus across modalities and species exhibit disinhibitory rebound responses following the removal of preceding inhibitory inputs (Grenier et al., 1998; Yu et al., 2004). The strength of the disin- hibitory rebound is correlated with the strength of the preceding inhibitory input (Wang et al., 2016). Our results of stronger offset responses for $\mathrm{ON}$ cells are consistent with the above observations, yet our measurements of "inhibition" are indirect, which makes it harder for us to assess this directly. We should emphasize that both $\mathrm{ON}$ and $\mathrm{OFF}$ cell responses will be integrated at higher levels of visual processing, and it is the relative balance of these two channels that underlies the perceptual outcome.

Another possible account for the observed dominance of $\mathrm{ON}$ cells over OFF cells in the offset responses comes from the observation that most rod bipolar cells are of the ON-subtype (Müller et al., 1988), thus giving stronger weight to ON retinal ganglion 
and dLGN cells. This may cause stronger poststimulus responses for ON cells than for OFF cells after the removal of stimuli of opposite polarity (Peter Schiller, personal communication). However, such an explanation is unlikely as the background luminance of the screen was $60 \mathrm{~cd} / \mathrm{m}^{2}$, which is well in the photopic range to saturate rods (Enroth-Cugell et al., 1977; Commission Internationale de l'Eclairage, 1978). Thus, in our cat experiments, it seems likely that only cones respond to luminance changes of the offset of opposite-sign stimuli.

\section{Adaptation of poststimulus responses between $\mathrm{ON}$ and OFF cells}

Under photopic conditions, multiple adaptation mechanisms occur across the majority of cell types and synapses from the photoreceptor onwards (Shapley and Enroth-Cugell, 1984). It has been shown that both fast and slow levels of adaptation exist in the retina of many species (Yeh et al., 1996; Smirnakis et al., 1997; Chander and Chichilnisky, 2001; Kim and Rieke, 2001). For fast adaptation, cone mechanisms have been indirectly estimated to exhibit time constant on the order of milliseconds (Smith et al., 2008), and Zaidi et al. (2012) have suggested that the retinal adaptation they observe for color afterimages involve slower postreceptoral mechanisms. In primates, there is also evidence suggesting greater levels of slow contrast adaptation for the ON pathway than the OFF pathway (Chander and Chichilnisky, 2001). The type of stimuli used in these studies (temporal contrasts) is not directly comparable with our stationary opposite-sign stimuli. We cannot discount an influence of different levels of photoreceptor adaptation to our luminance steps; however, the difference between $\mathrm{ON}$ and OFF responses lasts for substantially longer than the time course of adaptation estimated for the photoreceptors. This effect of longer stimulus adaptation was only observed in the dLGN recordings, and the difference between dLGN ON and OFF poststimulus responses became more pronounced at $4 \mathrm{~s}$ stimulus duration, consistent with our human psychophysical results (Fig. 2E).

\section{Latency of poststimulus response between $\mathrm{ON}$ and OFF cells} We found that the poststimulus response of ON cells to oppositesign stimuli in both retina and dLGN (though stronger) were delayed in latency compared with OFF cells. Previous studies in the retina of cold-blooded salamanders and turtles have consistently found that the response latency of OFF cells is shorter than that of ON cells to the same-sign stimuli (Baylor and Fettiplace, 1977; Copenhagen et al., 1983; Burkhardt et al., 1998; Gollisch and Meister, 2008). This difference can be explained by the fast response of OFF bipolars via AMPA receptors. However, latency difference for ON and OFF cells in mammals is not consistent across different species in different studies with different methodologies (Benardete and Kaplan, 1999; Chichilnisky and Kalmar, 2002; Jin et al., 2011; Nichols et al., 2013). For example, Jin and colleagues used white noise stimuli and spike-triggered averaging to show that OFF cells have shorter latency in response to dark stimuli than ON cells to bright stimuli (Jin et al., 2011). In another in vitro study of the monkey retina (Chichilnisky and Kalmar, 2002), the authors also used white noise stimuli and reported that ON cells responded faster than OFF cells to the same-sign bright and dark stimuli, respectively. The different experimental approaches across different species as well as differences in eccentricity may underlie the differences of ON and OFF cells observed between these two studies. In our study, by using bright and dark discs flashed on a mean gray background, we did not find a statistical difference between ON and OFF cells in responding to the onset of the same-sign stimuli (Fig. 5D). However, for offsets of opposite-sign stimuli, we found that OFF cells responded faster than $\mathrm{ON}$ cells (Fig. $5 A, B$ ). In addition, we found that both types of cells exhibited shorter response latencies to the removal of the opposite-sign stimuli than to the onset of the same-sign stimuli (Fig. 5E), suggesting a faster generation of poststimulus spikes by a sudden release of the preceding inhibition. Because dark stimuli inhibited ON cells more than bright stimuli for OFF cells (Fig. 7), the membrane potential of OFF cells recovered more quickly than $\mathrm{ON}$ cells when the preceding inhibitory inputs were removed.

\section{Asymmetries are differently distributed in $\mathrm{X}$ cells and $\mathrm{Y}$ cells}

In the retina and dLGN, X cells in cat and parvocellular cells in monkey show more linear responses to the luminance contrast changes, encoding preferentially edge and other form information; while Y cells in cat and magnocellular cells in monkey are more sensitive to temporal events and thus are presumed to be better tuned for motion detection (Enroth-Cugell and Robson, 1966; Shapley and Hochstein, 1975; Derrington and Fuchs, 1979; Lehmkuhle et al., 1980; Kaplan and Shapley, 1982; Marrocco et al., 1982; Demb et al., 2001). In our study, we found that the asymmetry in poststimulus response strength between $\mathrm{ON}$ and OFF cells are driven largely by X cells. Y cells exhibited a larger asymmetry in their response latencies to the offset of oppositesign stimuli. As discussed above, $\mathrm{Y}$ cells did not show a significant amount of opposite-sign inhibition; therefore, the latency asymmetries must depend on an additional mechanism specific to the Y-channel. Our results are consistent with earlier studies in human psychophysics and monkey electrophysiological single-unit recordings, suggesting that parvocellular cells are engaged in generating the neural representation of the afterimage (Ingling and Grigsby, 1990; Kelly and Martinez-Uriegas, 1993; McLelland et al., 2009). However, Schiller and Dolan (1994) found that after lesions in the parvocellular layers of dLGN, monkeys could still perceive afterimages, suggesting that both parvocellular and magnocellular cells can signal afterimage information (Schiller and Dolan, 1994).

In conclusion, the retina has long been thought to be the neural locus of negative afterimages (Barlow, 1964; Jung, 1973; Schiller and Dolan, 1994; Schiller, 1995; Schiller and Tehovnik, 2008). However, there is a broad body of evidence that a retinal explanation is not sufficient to account for all types of negative afterimages. One example that cannot be explained at the retinal level is the afterimage induced by a perceptually filled-in surface (Varin, 1971; Shimojo et al., 2001). It has also been observed that flickering light presented to one eye can prolong the afterimage duration of the other eye (Gerling and Spillmann, 1987; Tsuchiya and Koch, 2005). Furthermore, attention can affect afterimage perception (Suzuki and Grabowecky, 2003), as can high level cognitive classifications like gender (Utz and Carbon, 2015). Our observation of differences between poststimulus responses of $\mathrm{ON}$ and OFF cells in cat dLGN mirror psychophysical asymmetries for the bright and dark negative afterimages, and suggests that such asymmetries are initially mediated by mechanisms driving the subcortical ON and OFF channels differentially.

\section{References}

Ahmad KM, Klug K, Herr S, Sterling P, Schein S (2003) Cell density ratios in a foveal patch in macaque retina. Vis Neurosci 20:189-209. CrossRef Medline

Bachy R, Zaidi Q (2014) Factors governing the speed of color adaptation in foveal versus peripheral vision. J Opt Soc Am A Opt Image Sci Vis 31: A220-A225. CrossRef Medline 
Barlow HB (1953) Summation and inhibition in the frog's retina. J Physiol 119:69-88. CrossRef Medline

Barlow HB (1964) Dark-adaptation: a new hypothesis. Vision Res 4:47-58. CrossRef Medline

Baumgartner G (1961) Die reaktionen der neurone des zentralen visuellen systems der katze im simultanen helligkeitskontrast. In: Neurophysiologie und psychophysik des visuellen systems (Jung R, Kornhuber H, eds), pp 296-313. Berlin: Springer.

Baylor DA, Fettiplace R (1977) Kinetics of synaptic transfer from receptors to ganglion cells in turtle retina. J Physiol 271:425-448. CrossRef Medline

Benardete EA, Kaplan E (1999) Dynamics of primate p retinal ganglion cells: Responses to chromatic and achromatic stimuli. J Physiol 519:775790. CrossRef Medline

Bishop PO, Burke W, Davis R (1958) Synapse discharge by single fibre in mammalian visual system. Nature 182:728-730. CrossRef Medline

Bishop PO, Burke W, Davis R (1962) The interpretation of the extracellular response of single lateral geniculate cells. J Physiol 162:451-472. CrossRef Medline

Blackwell HR (1946) Contrast thresholds of the human eye. J Opt Soc Am 36:624-643. CrossRef Medline

Buchner A, Baumgartner N (2007) Text: background polarity affects performance irrespective of ambient illumination and colour contrast. Ergonomics 50:1036-1063. CrossRef Medline

Burkhardt DA, Fahey PK, Sikora M (1998) Responses of ganglion cells to contrast steps in the light-adapted retina of the tiger salamander. Vis Neurosci 15:219-229. Medline

Chander D, Chichilnisky EJ (2001) Adaptation to temporal contrast in primate and salamander retina. J Neurosci 21:9904-9916. Medline

Chichilnisky EJ, Kalmar RS (2002) Functional asymmetries in ON and OFF ganglion cells of primate retina. J Neurosci 22:2737-2747. Medline

Chubb C, Nam JH (2000) Variance of high contrast textures is sensed using negative half-wave rectification. Vision Res 40:1677-1694. CrossRef Medline

CIE Commission Internationale de l'Eclairage (1978) Light as a true visual quantity: principles of measurement. Commission Internationale de l'Eclairage publication 41.

Cleland BG, Dubin MW, Levick WR (1971) Sustained and transient neurones in the cat's retina and lateral geniculate nucleus. J Physiol 217:473496. CrossRef Medline

Copenhagen DR, Ashmore JF, Schnapf JK (1983) Kinetics of synaptic transmission from photoreceptors to horizontal and bipolar cells in turtle retina. Vision Res 23:363-369. CrossRef Medline

Demb JB, Zaghloul K, Sterling P (2001) Cellular basis for the response to second-order motion cues in Y retinal ganglion cells. Neuron 32:711-721. CrossRef Medline

Derrington AM, Fuchs AF (1979) Spatial and temporal properties of X cells and Y cells in the cat lateral geniculate nucleus. J Physiol 293:347-364. CrossRef Medline

Engbert R, Mergenthaler K (2006) Microsaccades are triggered by low retinal image slip. Proc Natl Acad Sci U S A 103:7192-7197. CrossRef Medline

Enroth-Cugell C, Robson JG (1966) The contrast sensitivity of retinal ganglion cells of the cat. J Physiol 187:517-552. CrossRef Medline

Enroth-Cugell C, Hertz G, Lennie P (1977) Cone signals in the cat's retina. J Physiol 269:273-296. CrossRef Medline

Gerling J, Spillmann L (1987) Duration of visual afterimages on modulated backgrounds: postreceptoral processes. Vision Res 27:521-527. CrossRef Medline

Gollisch T, Meister M (2008) Rapid neural coding in the retina with relative spike latencies. Science 319:1108-1111. CrossRef Medline

Grenier F, Timofeev I, Steriade M (1998) Leading role of thalamic over cortical neurons during postinhibitory rebound excitation. Proc Natl Acad Sci U S A 95:13929-13934. CrossRef Medline

Hartline HK (1938) The response of single optic nerve fibers of the vertebrate eye to illumination of the retina. Am J Physiol 121:400-415.

Herrick RM (1956) Foveal luminance discrimination as a function of the duration of the decrement or increment in luminance. J Comp Physiol Psychol 49:437-443. CrossRef Medline

Hochstein S, Shapley RM (1976) Linear and nonlinear spatial subunits in Y cat retinal ganglion cells. J Physiol 262:265-284. CrossRef Medline

Hubel DH, Wiesel TN (1961) Integrative action in the cat's lateral geniculate body. J Physiol 155:385-398. CrossRef Medline
Ingling JC Jr, Grigsby SS (1990) Perceptual correlates of magnocellular and parvocellular channels: seeing form and depth in afterimages. Vision Res 30:823-828. CrossRef Medline

Jin J, Wang Y, Lashgari R, Swadlow HA, Alonso JM (2011) Faster thalamocortical processing for dark than light visual targets. J Neurosci 31:1747117479. CrossRef Medline

Jin JZ, Weng C, Yeh CI, Gordon JA, Ruthazer ES, Stryker MP, Swadlow HA, Alonso JM (2008) On and OFF domains of geniculate afferents in cat primary visual cortex. Nat Neurosci 11:88-94. CrossRef Medline

Jones HE, Andolina IM, Shipp SD, Adams DL, Cudeiro J, Salt TE, Sillito AM (2015) Figure-ground modulation in awake primate thalamus. Proc Natl Acad Sci U S A 112:7085-7090. CrossRef Medline

Jung R (1973) Visual perception and neurophysiology. In: Handbook of sensory physiology, Vol VII/3: a central visual information, pp 1-152. Berlin: Springer.

Kaplan E, Shapley R (1984) The origin of the S (slow) potential in the mammalian lateral geniculate nucleus. Exp Brain Res 55:111-116. Medline

Kaplan E, Shapley RM (1982) X and Y cells in the lateral geniculate nucleus of macaque monkeys. J Physiol 330:125-143. CrossRef Medline

Kelly DH, Martinez-Uriegas E (1993) Measurements of chromatic and achromatic afterimages. J Opt Soc Am A 10:29-37. CrossRef Medline

Kim KJ, Rieke F (2001) Temporal contrast adaptation in the input and output signals of salamander retinal ganglion cells. J Neurosci 21:287-299. Medline

Kleiner M, Brainard D, Pelli D (2007) What's new in psychtoolbox-3? Perception 36:14.

Komban SJ, Alonso JM, Zaidi Q (2011) Darks are processed faster than lights. J Neurosci 31:8654-8658. CrossRef Medline

Komban SJ, Kremkow J, Jin J, Wang Y, Lashgari R, Li X, Zaidi Q, Alonso JM (2014) Neuronal and perceptual differences in the temporal processing of darks and lights. Neuron 82:224-234. CrossRef Medline

Kontsevich LL, Tyler CW (1999) Nonlinearities of near-threshold contrast transduction. Vision Res 39:1869-1880. CrossRef Medline

Kremers J, Lee BB, Pokorny J, Smith VC (1993) Responses of macaque ganglion cells and human observers to compound periodic waveforms. Vision Res 33:1997-2011. CrossRef Medline

Kremkow J, Jin J, Komban SJ, Wang Y, Lashgari R, Li X, Jansen M, Zaidi Q, Alonso JM (2014) Neuronal nonlinearity explains greater visual spatial resolution for darks than lights. Proc Natl Acad Sci U S A 111:3170-3175. CrossRef Medline

Krüger J, Fischer B (1975) Symmetry between the visual B- and D-systems and equivalence of center and surround: studies of light increment and decrement in retinal and geniculate neurons of the cat. Biol Cybern 20: 223-236. CrossRef Medline

Kuffler SW (1953) Discharge patterns and functional organization of mammalian retina. J Neurophysiol 16:37-68. Medline

Lee BB, Virsu V, Creutzfeldt OD (1983) Linear signal transmission from prepotentials to cells in the macaque lateral geniculate nucleus. Exp Brain Res 52:50-56. Medline

Lehmkuhle S, Kratz KE, Mangel SC, Sherman SM (1980) Spatial and temporal sensitivity of X-and Y-cells in dorsal lateral geniculate nucleus of the cat. J Neurophysiol 43:520-541. Medline

Liang Z, Freed MA (2010) The ON pathway rectifies the OFF pathway of the mammalian retina. J Neurosci 30:5533-5543. CrossRef Medline

Liang Z, Freed MA (2012) Cross inhibition from ON to OFF pathway improves the efficiency of contrast encoding in the mammalian retina. J Neurophysiol 108:2679-2688. CrossRef Medline

Manookin MB, Beaudoin DL, Ernst ZR, Flagel LJ, Demb JB (2008) Disinhibition combines with excitation to extend the operating range of the OFF visual pathway in daylight. J Neurosci 28:4136-4150. CrossRef Medline

Marrocco RT, McClurkin JW, Young RA (1982) Spatial summation and conduction latency classification of cells of the lateral geniculate nucleus of macaques. J Neurosci 2:1275-1291. Medline

McLelland D, Ahmed B, Bair W (2009) Responses to static visual images in macaque lateral geniculate nucleus: implications for adaptation, negative afterimages, and visual fading. J Neurosci 29:8996-9001. CrossRef Medline

Müller F, Wässle H, Voigt T (1988) Pharmacological modulation of the rod pathway in the cat retina. J Neurophysiol 59:1657-1672. Medline

Nelson SB (1991) Temporal interactions in the cat visual system: II. Suppressive and facilitatory effects in the lateral geniculate nucleus. J Neurosci 11:357-368. Medline 
Nichols Z, Nirenberg S, Victor J (2013) Interacting linear and nonlinear characteristics produce population coding asymmetries between $\mathrm{ON}$ and OFF cells in the retina. J Neurosci 33:14958-14973. CrossRef Medline

Prins N (2013) The psi-marginal adaptive method: how to give nuisance parameters the attention they deserve (no more, no less). J Vis 13:3. CrossRef Medline

Prins N, Kingdom FAA (2009) Palamedes: MATLAB routines for analyzing psychophysical data. http://www.palamedestoolbox.org.

Ratliff CP, Borghuis BG, Kao YH, Sterling P, Balasubramanian V (2010) Retina is structured to process an excess of darkness in natural scenes. Proc Natl Acad Sci U S A 107:17368-17373. CrossRef Medline

Rekauzke S, Nortmann N, Staadt R, Hock HS, Schöner G, Jancke D (2016) Temporal asymmetry in dark-bright processing initiates propagating activity across primary visual cortex. J Neurosci 36:1902-1913. CrossRef Medline

Schiller PH (1982) Central connections of the retinal ON and OFF pathways. Nature 297:580-583. CrossRef Medline

Schiller PH (1995) The ON and OFF channels of the mammalian visual system. Prog Retinal Eye Res 15:173-195. CrossRef

Schiller PH, Dolan RP (1994) Visual aftereffects and the consequences of visual-system lesions on their perception in the rhesus-monkey. Vis Neurosci 11:643-665. CrossRef Medline

Schiller PH, Tehovnik EJ (2008) Visual prosthesis. Perception 37:15291559. CrossRef Medline

Shapley R, Enroth-Cugell C (1984) Visual adaptation and retinal gain controls. Prog Retinal Res 31:263-346.

Shapley R, Hochstein S (1975) Visual spatial summation in two classes of geniculate cells. Nature 256:411-413. CrossRef Medline

Shimojo S, Kamitani Y, Nishida S (2001) Afterimage of perceptually filled-in surface. Science 293:1677-1680. CrossRef Medline

Short AD (1966) Decremental and incremental visual thresholds. J Physiol 185:646-654. CrossRef Medline

Sincich LC, Adams DL, Economides JR, Horton JC (2007) Transmission of spike trains at the retinogeniculate synapse. J Neurosci 27:2683-2692. CrossRef Medline

Singer W, Creutzfeldt OD (1970) Reciprocal lateral inhibition of ON- and off-center neurones in the lateral geniculate body of the cat. Exp Brain Res 10:311-330. Medline

Smirnakis SM, Berry MJ, Warland DK, Bialek W, Meister M (1997) Adaptation of retinal processing to image contrast and spatial scale. Nature 386:69-73. CrossRef Medline

Smith VC, Pokorny J, Lee BB, Dacey DM (2008) Sequential processing in vision: the interaction of sensitivity regulation and temporal dynamics. Vision Res 48:2649-2656. CrossRef Medline

Suzuki S, Grabowecky M (2003) Attention during adaptation weakens negative afterimages. J Exp Psychol Hum Percept Perform 29:793-807. CrossRef Medline

Tamura H, Tanaka K (2001) Visual response properties of cells in the ventral and dorsal parts of the macaque inferotemporal cortex. Cereb Cortex 11:384-399. CrossRef Medline

Tsuchiya N, Koch C (2005) Continuous flash suppression reduces negative afterimages. Nat Neurosci 8:1096-1101. CrossRef Medline

Utz S, Carbon CC (2015) Afterimages are biased by top-down information. Perception 44:1263-1274. CrossRef Medline

Varin D (1971) Fenomeni di contrasto e diffusione cromatica nell'organizzazione spaziale del campo percettivo. Rivista Psicologia 65:101-128.

Wang XX, Jin Y, Sun H, Ma C, Zhang J, Wang M, Chen L (2016) Characterization of rebound depolarization in neurons of the rat medial geniculate body in vitro. Neurosci Bull 32:16-26. CrossRef Medline

Wheatstone C (1838) Contributions to the physiology of vision: I. On some remarkable, and hitherto unobserved, phenomena of binocular vision. Philos Trans R Soc Lond 128:371-394.

Whittle P (1986) Increments and decrements: Luminance discrimination. Vision Res 26:1677-1691. CrossRef Medline

Xing D, Yeh CI, Shapley RM (2010) Generation of black-dominant responses in v1 cortex. J Neurosci 30:13504-13512. CrossRef Medline

Yeh CI, Xing D, Shapley RM (2009) "Black" responses dominate macaque primary visual cortex v1. J Neurosci 29:11753-11760. CrossRef Medline

Yeh T, Lee BB, Kremers J (1996) The time course of adaptation in macaque retinal ganglion cells. Vision Res 36:913-931. CrossRef Medline

Yu YQ, Xiong Y, Chan YS, He J (2004) Corticofugal gating of auditory information in the thalamus: an in vivo intracellular recording study. J Neurosci 24:3060-3069. CrossRef Medline

Zaghloul KA, Boahen K, Demb JB (2003) Different circuits for ON and OFF retinal ganglion cells cause different contrast sensitivities. J Neurosci 23: 2645-2654. Medline

Zaidi Q, Ennis R, Cao D, Lee B (2012) Neural locus of color afterimages. Curr Biol 22:220-224. CrossRef Medline

Zemon V, Gordon J, Welch J (1988) Asymmetries in ON and OFF visual pathways of humans revealed using contrast-evoked cortical potentials. Vis Neurosci 1:145-150. CrossRef Medline

Zurawel G, Ayzenshtat I, Zweig S, Shapley R, Slovin H (2014) A contrast and surface code explains complex responses to black and white stimuli in v1. J Neurosci 34:14388-14402. CrossRef Medline 